\title{
Political Institutions and Policy Outcomes in Colombia: the Effects of the 1991 Constitution
}

\author{
Mauricio Cárdenas S. ${ }^{1}$ \\ Roberto Junguito $B .^{2}$ \\ Mónica Pachón B. ${ }^{3}$
}

\begin{abstract}
The 1991 Colombian Constitution strengthened the checks and balances by enhancing the role of Congress and the Constitutional Court, while somewhat limiting the powers of the President. As a consequence of the larger number of relevant players, and the removal of barriers that restricted political participation, the political system has gained in terms of representation. However, political transaction costs have increased, making cooperation harder to achieve. This has been typically the case in fiscal policy, where the use of rigid rules have limited the adaptability and flexibility of policies. In other areas of policy, such as monetary policy and regulation of public utilities, policies have been more adaptable to economic shocks, delivering better outcomes.
\end{abstract}

\section{Resumen}

La Constitución de 1991 aumentó la injerencia del Congreso y la Corte Constitucional en el proceso político y redujo los poderes del ejecutivo, fortaleciendo así el sistema de pesos y contrapesos. A pesar de que ahora el sistema es más representativo, el mayor número de jugadores aumentó los costos políticos de transacción, lo que hace más difícil la cooperación entre ellos. Esto ha sido particularmente cierto en la política fiscal, donde un Congreso más fragmentado y dividido ha resultado en un mayor uso de inflexibilidades. En otras áreas de política, como la monetaria y la regulación de los servicios públicos, las políticas se han caracterizado por una mayor adaptabilidad.

Keywords: Political Institutions, Policymaking, Policy Outcomes.

Palabras clave: Instituciones políticas, economía política, elaboración y resultados de políticas públicas.

Clasificación JEL: E61, E65, H11.

Primera versión recibida en marzo 5 de 2006; versión final aceptada en abril 26 de 2006.

Coyuntura Económica volumen xxxvı, No. 1, primer semestre de 2006, pp. 63-116. Fedesarrollo, Bogotá - Colombia.

\footnotetext{
1 Executive Director of Fedesarrollo.

2 President of Fasecolda.
}

3 PhD Student of the Department of Political Science, University of California. We thank Diego López, Miguel Rueda, and Sumie Tamura for excellent research assistance. We are particularly grateful to Ernesto Stein for his thoughtful comments at different stages during this project and to Alberto Alesina, Robert Bates, Mauricio Olivera, Jacint Jordana, Carlos Malamud, Pablo Spiller, Jorge Streb, Mariano Tommasi, and participants at seminars at Harvard University, Fedesarrollo, Universidad de los Andes, LACEA's Political Economy Group, an informal meeting between Colombian lawyers and economists organized by the Ministry of Finance, and the IDB-BBVA workshop, for their valuable comments. We acknowledge funding from the Banco de la República and the Inter-American Development Bank. 


\section{INTRODUCTION}

In an influential volume edited by Rudiger Dornbusch and Sebastian Edwards on the macroeconomics of populism in Latin America, Miguel Urrutia (1991) argued that populist macroeconomics were absent in Colombia, contrary to the norm in the rest of South America. According to the definition used in that volume, one feature of populist economics is the presence of large fiscal deficits, reflecting the use of budget expenditures for redistributive purposes without a concurrent effort to raise tax revenues. As shown in Figure 1, for most of the past century fiscal deficits in Colombia were relatively small (rarely exceeding 4 percent of GDP) and, when present, rapidly corrected. ${ }^{4}$ Moreover, the public sector was relatively small by regional standards (aggregate expenditures and revenues of the consolidated public sector were around 20 percent of GDP between 1960 and 1990).

Figure 1. COLOMBIA: FISCAL VARIABLES

Central Government's Operations as \% GDP (1905-2003)

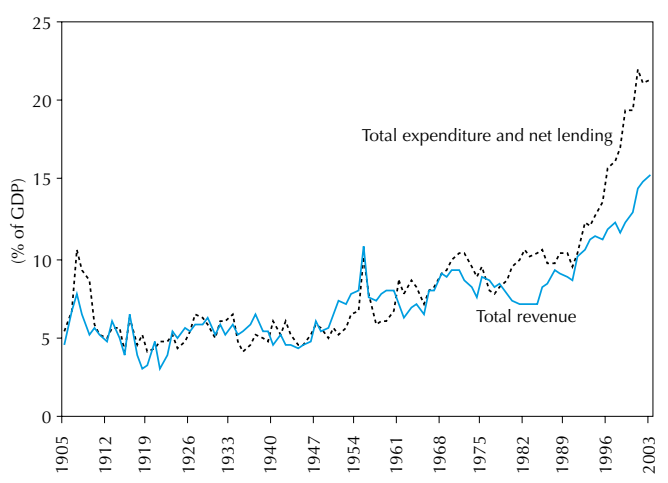

Overall Public Sector's Operations as \% GDP (1981-2003)

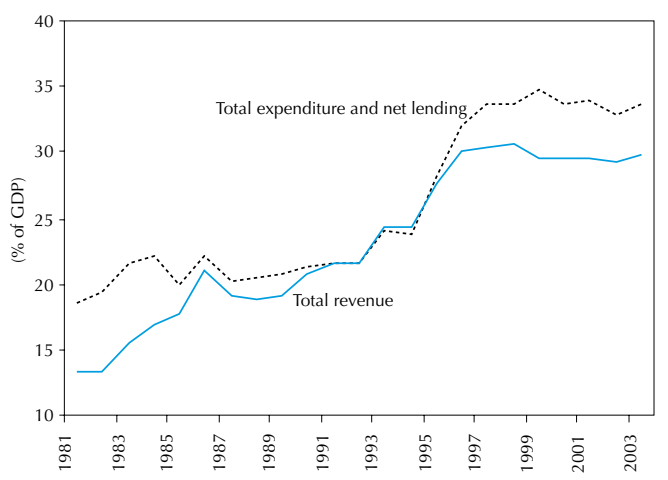

Central Government's Total Balance

(1905-2003)

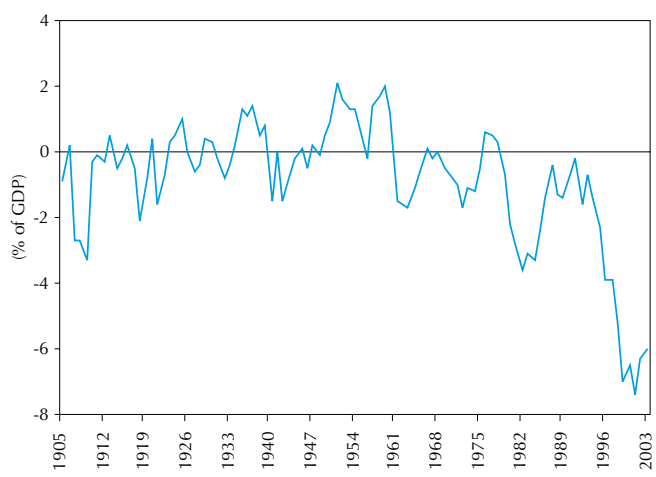

Overall Public Sector's Total Balance (1981-2003)

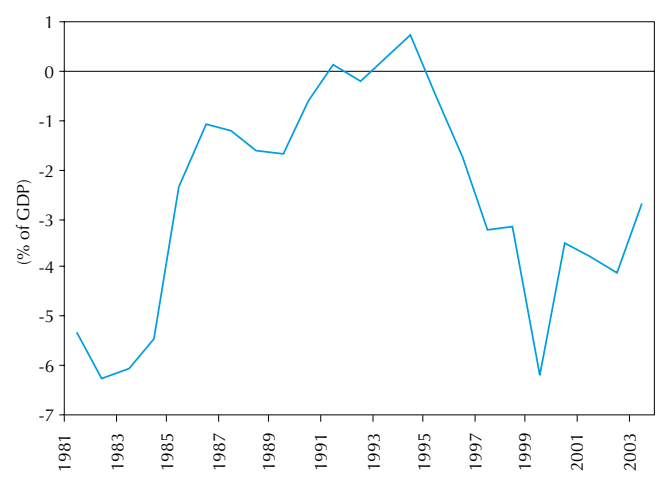

Source: Junguito and Rincón (2004) and DNP. 
Fiscal policy outcomes have changed significantly since the early 1990s. As Figure 1 also shows, there has been a strong deterioration of the fiscal balance. The deficit of the central government has been close to 7 percent of GDP since the late 1990s, without a clear indication of a major correction. The deterioration of the consolidated public sector (CPS) balance is also apparent. Aggregate public expenditures grew to 33.7 percent of GDP in 2003 from 21.2 percent in 1990, reflecting a deliberate effort to increase the size of the state and use fiscal expenditures for redistribution. The fact that total revenues grew to 29.7 percent of GDP in 2003 from 20.6 percent in 1990, suggests that the decision to raise government expenditures was accompanied by an effort on the revenue side. However, the effort was insufficient. In fact, the data are unequivocal on the greater tolerance towards fiscal deficits in recent times. ${ }^{5}$ In the words of Carrasquilla (2003, p. 23), "it has not been feasible to consolidate a political agreement that excludes fiscal disequilibrium as an option for public and private agents". ${ }^{6}$

Until not too long ago, Colombia was regarded as a success story in terms of macroeconomic management. To a large extent, fiscal policy played a stabi-

\footnotetext{
$4 \quad$ Urrutia argued that the particular political development of Colombia had led to clientelism rather than populism. His hypothesis was that local politicians were not interested in populist macroeconomic policies because the electorate had a very low tolerance for inflation, so that "neither local politicians nor the head of the state are willing to risk the wrath of the public by supporting expansionist fiscal or monetary policies " (p. 379).
}

\begin{abstract}
5 Ocampo (2004) argues "the Gaviria (1990-94) and Samper Administrations (1994-98) did not have the explicit purpose of raising the fiscal deficit, but rather to increase the size of the state in an orderly manner", concluding that recent fiscal policy in Colombia cannot be characterized as populist macroeconomics in the sense of Dornbusch and Edwards (1991).
\end{abstract}

$6 \quad$ "Political" explanations of the fiscal deficit in Colombia have a long tradition among economists. See, for example, Wiesner (2004). lizing role, which resulted in low economic volatility (i.e., low variance in GDP growth rates) between 1960 and 1990. The structural deficit in the public sector has restricted the adoption of countercyclical fiscal policies precisely at a time when external shocks have become more severe. As a result, economic fluctuations have been much larger since 1990. In addition, GDP growth during the 1990s fell to 2.9 percent per year from a 4.7 percent annual average between 1950 and 1990. Urban unemployment rates reached 20 percent in 1999, almost twice the 1978-1990 average, and income concentration has increased since the early 1990s, after decades of falling inequality. In terms of poverty, various meares also suggest a reversal. Conversely, in the case of monetary policy, results show an improvement. After decades of doubledigit inflation (see Figure 2), inflation rates have fallen since 1990, reflecting the effectiveness of new political institutions that ruled out high inflation as an outcome.

The purpose of this paper is to understand the causes of the change in the quality of policies as well as their outcomes improvement in some areas and deterioration in others. We focus on fiscal and monetary policies, but the analysis can easily be extended to

\section{Figure 2. ANNUAL INFLATION RATE}

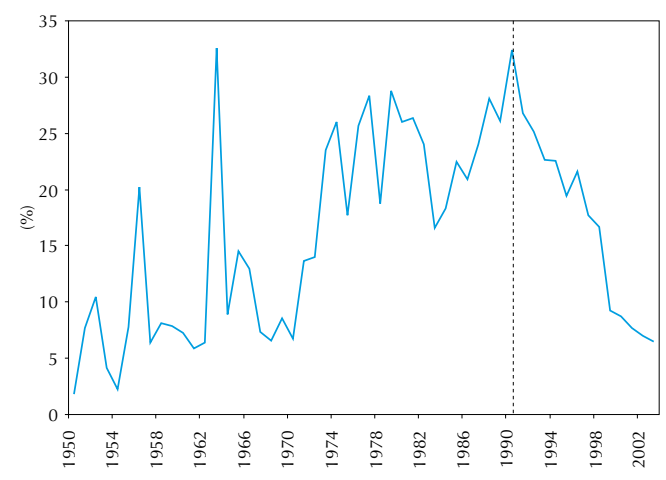

Source: Banco de la República. 
other areas of policy, such as trade policy and the regulation of public utilities. Rather than analyzing the details, we identify some common characteristics of policies and the policymaking process (PMP) that can be related to changes in the political institutions. More precisely, our goal is to understand how relevant political institutions, such as the constitution, map into political behavior, political behavior into policymaking processes, and policymaking processes into policies and policy outcomes.

It is analytically tempting to focus on the effects of the 1991 Constitution, which changed the rules of the political game along multiple dimensions. The new constitution strengthened the checks and balances of the political system in an effort to endow political institutions with greater legitimacy after decades of limited participation and low representation. Although remaining extremely powerful even by Latin American standards -surpassed only by the Brazilian executive- the President lost some capacity as an agenda-setter relative to the previous period, while Congress and the Constitutional Court (cc) gained relative power. As a consequence of the larger number of relevant players and the diminished presidential powers, political transaction costs increased in several policy areas. In a nutshell, the tension between representation and cooperation was shifted in favor of the former.

In addition to the changes in the number of key players, as well as in the rules of the political game, the new constitution covered many specific, previously non-constitutional, aspects of policy. This is particularly the case of fiscal policy, where key components of public expenditures, such as pensions, fiscal transfers for education and health, and public sector wages, were "hard-wired" into the constitution. ${ }^{7}$ Many observers have suggested that these embedded rigidities, have been a major source of growing fiscal deficits and public debt, tax uncertainty, and inefficient government expenditures, which are frequently mentioned as the causes of macroeconomic instability and low growth. ${ }^{8}$ In an extreme form of rigidity, changes in fiscal policy oftentimes require constitutional reform, which by definition is slow and costly. ${ }^{9}$ As a result, fiscal policies are not stable and adaptable to shocks, in sharp contrast to Colombia's own previous experience.

In contrast, monetary and exchange rate policies have been formally delegated to the technocracy since 1991. This has been a result of the constitution, which granted independence to the board of the central bank, and the appointment of technocrats to the board by successive presidents. In addition, the constitution prevented direct monetary financing of specific economic sectors, including the government. ${ }^{10}$ As a result, policies have been more stable, coherent and publicly regarded since 1991. Policies have also been partially flexible and adaptable (to external shocks), more so after the central bank's success in bringing inflation down -an instance in which flexibility was initially sacrificed in order to gain credibility.

It is also interesting to discuss whether larger fiscal deficits have been the result of changes in monetary

\footnotetext{
According to the IMF (2004a), 80 percent of the budget is predetermined by constitutional or legal mandates, resulting in one the most rigid budgets in Latin America.

8 See for example, the reports of two important technical missions: Comisión de Racionalización del Gasto y de las Finanzas Públicas (1997) and Misión del Ingreso Público (2003).

9 There have been 18 constitutional amendments since 1991. In contrast, the 1886 Constitution was amended 63 times in 105 years.

10 Decisions to provide loans to the government are not forbidden but require the unanimous vote of all board members, implying that in practice they have not taken place.
} 
policy. Here, the evidence provided by Villar (2004) suggests that although central bank independence has reduced potential fiscal seignorage (i.e., the share of seignorage that benefits directly the government), the historical fact is that fiscal seignorage was never high in Colombia, except during the early 1980s. Therefore, central bank independence and the reduction in seignorage revenues do not explain the growing fiscal imbalances since the mid-1990s.

To develop the argument, the paper proceeds in the following way. In Section 2 we familiarize the reader with some historical background about Colombia. Section 3 presents the conceptual framework and defines those features of policies that are the dependent variables of our analysis. Section 4 describes the key political actors in Colombia: the President, Congress, political parties, and the cc. The idea is to show how the relative powers of the different players have evolved throughout time. Section 5 discusses the policymaking process in Colombia, with special emphasis on those aspects that changed after the 1991 Constitution. Section 6 presents the empirical exercises, using a database containing 3,428 bills discussed in Congress during the last 20 years. The main point of the exercise is to document the relative reduction in presidential powers, measured by the increased difficulty of the executive in enacting laws in Congress. More importantly, the evidence suggests that the fragmentation of Congress (through more lists and more parties) explains the greater difficulty in passing laws. Sections 7 and 8 discuss in more detail the salient features or outer characteristics of fiscal and monetary policies, respectively, and illustrate the policymaking processes in both cases. The paper concludes with Section 9, a summary of the main findings and some preliminary remarks on the policy implications of two recent institutional changes: the possibility of presidential reelection and the reform of electoral rules.

\section{HISTORICAL BACKGROUND}

In 1958, after 10 years of political violence between the two traditional parties (Liberal and Conservador), and four years of a military government (19531957), the traditional parties' leaders agreed to share power during four presidential terms, between 1958 and $1974 .{ }^{11}$ In addition to alternation in the party affiliation of presidents, the agreement (initially a referendum and later a constitutional amendment) included a strict "parity" between the two parties in the key policymaking arenas, such as Congress, cabinet positions, courts, governors and mayors. Many features of this agreement survived after the "formal" end of the Frente Nacional in 1974.

In spite of their apparent success in terms of economic policy outcomes, the political institutions and the consequent rules of the political game derived from the Frente Nacional agreement were unsustainable. ${ }^{12}$ The agreement between Liberals and Conservatives excluded other sectors, most relevantly the left, which did not have access to a democratic channel for participating in the political process. Guerrilla activity became more intense, and the political system started to lose credibility due to patronage, corruption, and the entry of drug money into the political process. ${ }^{13}$ The exclusionary nature of the system, along with the lack of authority and presence of the State in parts of the country, eroded the Frente

\footnotetext{
11 The agreement's goal was to bring an end to partisan conflict, which had resulted in a large number of violent deaths in the period 1948-1958. As discussed in Chacón (2004), the exact figure is a highly contested issue.

12 In the terminology of Aghion, Alesina and Trebbi (2004), during the Frente Nacional the traditional parties were almost sure to rule, so a high level of insulation of the executive was functional. This led to economic stability, at the cost of political unrest, in a way that is reminiscent of the autocratic regimes in other countries in Latin America.
} 
Nacional's popular support, resulting in high rates of abstention. Guerrilla groups -such as the M19, EPL, ELN and FARC- as well as labor and social movements gained momentum in urban and rural areas.

Colombia's level of violence escalated during the 1980s, precisely when drug trafficking activities grew exponentially. According to Rocha (1999), between 1981 and 1990 the production of cocaine increased by 672 percent (from 52 to 398 tons). However, data from the United Nations Office on Drugs and Crime (2004) indicate that the production of cocaine in 1990 was 92 tons and that it rose to 695 tons in 2000, and then fell to 440 tons in 2003. Regardless of the source, there is clear indication of the rapid increase in drug trafficking activities between 1980 and 2000. In relation to the homicide rate, as shown in Figure 3, it is interesting to note that this variable reaches a peak in 1991 (89 homicides per 100,000 inhabitants), precisely when the new constitution was enacted. Since then, the homicide rate has been falling, although other crime indicators do not show the same trend. ${ }^{14}$

During the 1980s and early 1990s the Medellín and Cali drug cartels were very strong in terms of resources, controlling much of the illicit drug business, with growing political influence both regionally and nationally. The cartel's private armies, which later evolved into paramilitary (the so-called self-defense) groups, protected them from internal fights, extradition, and kidnapping by guerrillas. Eventually the drug lords were captured and the large cartels

\footnotetext{
13 Incidentally, the emergence of drug trafficking made local politicians became more independent from the party bosses in Bogota, which gradually lost control over the conformation of party lists.
}

14 See Levitt and Rubio (2005) and Cárdenas (2001) on the causes and consequences of crime in Colombia.

\section{Figure 3. CRIME INDICATORS}

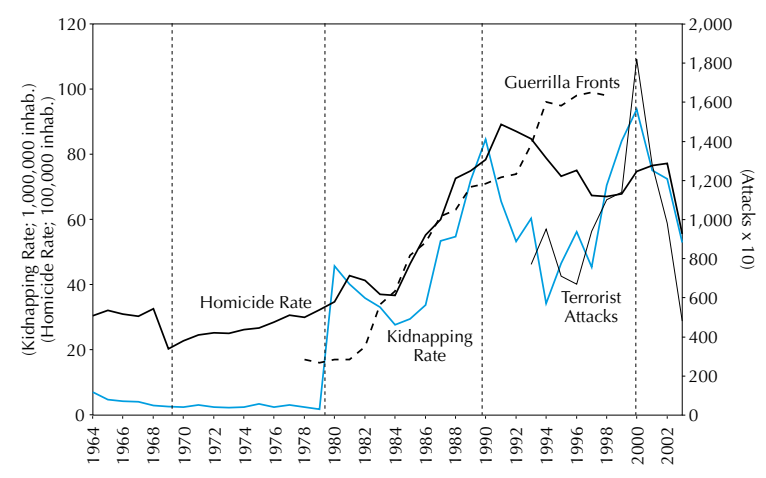

Source: Fedesarrollo (Análisis Coyuntural - Coyuntura Social No. 31, diciembre 2004); Guerrrilla Fronts: Rocha (1999); Terrorist Attacks: DNP; Kidnapping rates: Echandía (1999).

dismantled. However, the success of this strategy opened the door for the guerrilla and paramilitary groups to break into the drug business at a larger scale. It is a well-established fact that these groups derive an important amount of income from drug trafficking.

President Belisario Betancur (1982-1986) proposed a political rather than military solution to the guerrilla problem. In 1984, his government signed a truce agreement with the FARC and started negotiations with the M19, the two largest guerrilla groups at the time. These efforts failed, and the confrontation escalated to a higher level. In fact, the Palace of Justice was occupied in 1985 by the M19, resulting in the tragic death of the majority of the justices of the Supreme Court. In spite of the failure of the peace talks, the left created a new political party (Unión Patriótica) with strong links to the FARC, though with very limited electoral success. The experiment ended abruptly because many of its members were killed by paramilitary groups. In 1989, during the Barco Administration, the M19 (and other smaller insurgent groups) finally laid down their arms and entered the political process, with some success. 
The FARC responded by escalating the conflict with the cartels for the control of the drug business, increasing revenues derived from kidnappings and extortion (a strategy shared with the ELN), and establishing strongholds in areas rich in natural resources, but with relatively low state presence, from which they could derive rents. This was particularly the case of the regions where major oil discoveries took place during the 1980s (oil reserves were six times larger in 1990 than in 1980). Adopting similar strategies, the paramilitaries became increasingly independent from the drug cartels. As a result, the government decided to increase defense and security outlays, which explains part of the increase in public expenditures during the last two decades.

The assassination of three presidential candidates in 1989, including Luis Carlos Galán -the likely winnerelicited a popular demand for political reform. ${ }^{15}$ The long-debated idea of a constitutional reform gained popular support as a response to the political unrest, at a time when great importance was given to the successful incorporation of guerilla groups, especiaIly the M19, into the political system. ${ }^{16}$ Ultimately, it was the students' initiative through the movimiento séptima papeleta that succeeded in this effort. ${ }^{17}$ Dugas (2001) describes the process,

"In the final tally, the students estimated that approximately two million Colombians had cast extralegal ballots in favor of summoning a National Consti-

15 The candidates were Bernardo Jaramillo (UP), Carlos Pizarro (AD-M19) and Luis Carlos Galán (previously a dissident in the official Liberal Party, then competing for the party's nomination).

16 The proposals for political reform during the administrations of López and Turbay did not prosper. The most important one was López's Constitutional Assembly. Later, several bills were presented to Congress, without success, with the goal of institutionalizing political parties, providing guarantees to parties in the opposition, and improving the electoral system. See Hartlyn (1993). tuent Assembly. Although the seventh ballot had no legal standing it served as a striking indicator of public discontent with the existing political regime. In the aftermath of the March (1990) elections the proposal to establish a National Constituent Assembly gained momentum as all four major presidential candidates declared their support for this extraconstitutional mechanism" (p. 382).

President Virgilio Barco, in recognition of the people's will, issued Decree 927 of 1990 to authorize the introduction of a referendum onto the ballot of the May presidential elections calling for a Constitutional Assembly to reform the national constitution. The Supreme Court declared the constitutionality of the decree by admitting, at the same time, the state's incapacity to confront the different types of violence facing the nation (Lleras and Tangarife, 1996). The ballot, which became an official plebiscite, resulted in more than 5 million votes in favor of the National Constituent Assembly. President-elect Gaviria called for elections in December to organize the Constituent Assembly. The new constitution was adopted on July 4, 1991.

\section{CONCEPTUAL FRAMEWORK}

As mentioned in the introduction, the goal of this paper is to establish a link between the observed changes in policy outcomes and the changes in political institutions. Following the framework developed in Spiller, Stein and Tommasi (2003), Scartascini and Olivera (2003) and Spiller and Tommasi (2003), our

\footnotetext{
17 This refers to the fact that the student movement asked the electoral authorities to introduce a seventh ballot in the elections of March 1990 (the other six ballots were for the election of the Senate, House, governors, departmental assemblies, majors, and city councils). The ballot in support of the constitutional reform was unofficial, in the sense that it had to be counted by the students and did not have legal implications.
} 
task is not to analyze the details of specific policy areas. Rather than focusing on the policy outcomes directly, we want to identify those features or characteristics that tell us whether policies are optimal in the sense of being resilient to political shocks but flexible in adjusting to economic shocks.

In other words, we do not try to explain the content or substance of policies (such as whether the currency is overvalued), but rather certain common features or qualities of public policies, termed as outer features, that are systematically present in those policies. ${ }^{18}$ These features refer to aspects such as the stability/ volatility of policies. We consider that stable policies are those that can be sustained beyond the tenure of a particular government, whereas volatile policies show reversals associated with political events such as elections or cabinet reshufflings. Another related and useful dimension for the characterization of policies is their adaptability/rigidity. This refers to the fact that political actors sometimes try to prevent future policy reversals by embedding policies with rigidities. This is problematic, since policy adjustments are sometimes desirable in the sense of being welfare-improving. The degree of coordination or coherence among different political actors (e.g., different levels of government) is another interesting dimension that reflects the nature of the political game. The extent to which policies resemble public goods and promote the general welfare (in contrast to policies that produce mostly private benefits) is another relevant distinction. ${ }^{19}$

The general idea of the framework is that the ability to reach cooperative outcomes among the key po-

\footnotetext{
18 This choice is useful because the common features of policies are more naturally linked to the institutional environment than the content of policies. In addition, the focus on outer features also allows comparability across policy issues, which would not be possible with the contents of policies.
}

litical players affects the outer features of public policies. The key point here is that the specific political institutions -together with some particular aspects of the policies- determine whether cooperative intertemporal transactions are possible. When these transactions are feasible, public policies are more effective, more sustainable, and more adaptable. In contrast, when intertemporal political agreements are harder to reach and enforce, policies are either too unstable (in the sense of being subject to political swings) or too rigid (in the sense that players inefficiently tie their hands, rather than leaving some political discretion). As in oligopoly games, fewer political actors and lower immediate benefits from deviating are two key factors that facilitate cooperation. ${ }^{20}$

This framework encompasses other approaches that are useful for our analysis of political institutions and policy outcomes. Tsebelis (2002), for example,

\footnotetext{
19 Weaver and Rockman (1993) list 10 key "government capabilities" that are close to our outer features: i) To set and maintain priorities among the many conflicting demands made upon them so that they are not overwhelmed and bankrupt; ii) To target resources where they are most effective; iii) To innovate when old policies have failed; iv) To coordinate conflicting objectives into a coherent whole; v) To be able to impose losses on powerful groups; vi) To represent diffuse, unorganized interests in addition to concentrated, well-organized ones; vii) To ensure effective implementation of government policies once they have been decided upon; viii) To ensure policy stability so that policies have time to work; ix) To make and maintain international commitments in the realms of trade and national defense to ensure their long-term well-being; and x) To manage political cleavages in order to ensure that the society does not degenerate into civil war.
}

20 To add some notation, the outer features are the dependent variable $(\mathrm{Y})$ of the analysis. These features are the outcome of intertemporal political transactions among political actors, which in turn are conditioned by the rules of the political game, embodied in the political institutions (X). The specific political institutions depend on constitutional and historical determinants (W), which should not be considered as exogenous to the analysis. Each policy area also has its own specificities (Z), such as their time horizons, observability, irreversibility, etc. In sum, this approach maps the interaction of $X(\mathrm{~W})$ and $Z$ into $Y$. It should be noted that $\mathrm{Y}$, ultimately, has an impact on $\mathrm{W}$. 
focuses on the number, ideological differences, and internal level of cohesion of "veto players." Cox and McCubbins (2001) underscore the trade-off between the ability to change policy ("decisiveness") and the ability to commit to enacted policies ("resoluteness"). The larger the number of veto players, the closer policies would be to resoluteness rather than decisiveness. Cox and McCubbins (2001) provide another dimension to the analysis, relevant for Colombia, by distinguishing between the "separation of powers" (number of institutional veto points) from the "separation of purpose" (which refers to the diversity of interests of those controlling the veto points). This is the case, for example, when local politicians do not worry about national problems, in spite of the fact that they can act as veto points on national issues.

\section{KEY POLITICAL ACTORS IN THE POLICYMA- KING PROCESSES (PMPs)}

The entire set of characteristics of the PMPS, including the role of key and veto players, the policy initiation process and the effective number of parties, underwent important modifications during the late 1980s and early 1990s. This is mostly related to the end of the rules imposed by the Frente Nacional and the emergence of new political institutions. Since the drafting of the new constitution in 1991 is the most salient of these transformations, it is convenient to characterize key political actors and the corresponding PMPs before and after that year. However, two caveats are in order. First, some of the changes in the underlying political institutions preceded the 1991 Constitution, such as the initial steps of the decentralization process, including the direct election of majors (1986). Second, the transformation was not restricted to the constitution. Other factors, such as market-oriented reforms introduced in the early 1990s or the greater interest of the U.S. in Colombia in recent years, have had an impact on PMPS.
In order to characterize the PMPS it is necessary to determine which are the key actors that participate in it. ¿What powers and roles do these actors have? What preferences, incentives, and capabilities do they bring to the table? ¿And, what is the nature and frequency of their interactions?

\section{A. President}

As has been the case in most Latin American presidential regimes, an important number of constitutional prerogatives make the Colombian President the main agenda-setter in most policy areas. This is true even after the 1991 Constitution, which reduced presidential powers in a number of dimensions. Table 1 compares constitutional presidential powers before and after the 1991 Constitution.

\section{Proactive Powers}

The 1886 Constitution established a highly centralized power structure. The President controlled the budget and was constitutionally granted extraordinary legislative powers when invoking the state of siege. Even though the 1914, 1936 and 1945 constitutional amendments tried to diminish presidential powers, the 1968 constitutional reform promoted by president Lleras-Restrepo elevated them to a new level. In addition to strengthening the legislative initiation capacity of the President, the reform significantly increased executives' control over the budget. The President could exclusively introduce legislation in key areas, issue decree-laws when in crisis, and issue administrative decrees with limited judicial review.

The 1991 Constitution deliberately curbed the legislative powers of the President by limiting to 90 days the declaration of either a state of internal commotion, or a state of economic emergency, which can be extended for another 90 days if considered ne- 
National Front and transition

(1958-1980s)
After the 1991 Constitution

(1991-2004)
Proactive powers

High decree powers, urgency petition, ex-post judicial review, areas of exclusive introduction of legislation (from 1968), declaration of unrestricted state of siege and state of economic emergency.

Integrative powers

Appointment powers in the governorships, various autonomous agencies, cabinet (highly centralized).

Reactive powers

Required supermajority to override in economic bills ( $2 / 3$ of the members of each House).

Partisan powers

Relatively low due to consociational arrangement and electoral rules (quasi SNTV). Majority of 2/3 required in Congress (until 1974).
Restricted decree powers with ex-ante judicial review, call for joint permanent committees along with urgency petition. Declaration of state of siege for periods of 90 days, for a maximum of 180 days, subject to approval by the Constitutional Court

Appointment of the cabinet, autonomous agencies (highly decentralized).

Required majority to override: $1 / 2$ of the members of the House.

Extremely low: No nomination power, electoral rules. Non-concurrent elections-congressional elections first, majority runnoff system.

Source: Authors' data.

cessary for the state of internal commotion, and 30 days extended to a maximum of 90 days for the state of economic emergency. A third extension, however, requires previous consent from Congress. The cc may revoke decrees issued, including the declaration of the emergency or commotion, if they are considered unconstitutional in any way. Previously, decrees issued under state of siege became laws, even after their special status had expired. After 1991, decrees only remain in force if Congress enacts them in regular sessions. In addition, now the pro tempore powers cannot be used to decree codes, statutes, organic laws or taxes (see Archer and Shugart, 1997, p.123).

The presence of the cc has restrained the use of the president's special powers. Prior to 1991, the President only required the signatures of all his cabinet to use extraordinary powers to issue decree-laws in a 90-day time frame. Although the subject matter was supposedly narrow, in practice the President could freely use the emergency powers to make policy. The Supreme Court was the only veto gate, as it had the duty of reviewing each of the decrees enacted, but it was not as active and independent as the current cc. The judicial budget was determined by the executive, and the Supreme Court was elected from lists submitted by the President to the House of Representatives and the Senate. A critical aspect was that justices had short terms of five years, with the possibility of reelection. As we will discuss in detail below, now the cc is elected by the Senate for longer terms (eight years without reelection), with only one third of the lists submitted to the Senate originating in the executive.

One important aspect in which there has been no change is the president's permanent control over the legislative agenda by using the discharge or urgency petition. This petition enables the President to prioritize a bill in the legislators' agenda. Congress then has 30 days to debate and pass or reject the bill. The President can also ask for joint sessions of House and Senate committees in charge of the law in order to speed up the process, by limiting debates to two 
instead of the regular four. ${ }^{21}$ Also, the executive kept the exclusive right to introduce bills concerning the structure of the ministries, salaries of public employees, foreign exchange, budget, external trade and tariffs, and national debt, among other areas.

\section{Integrative Powers}

Prior to 1991, the President had greater appointment powers (governors, justices, and heads of control entities, among others). The President also appointed the governor of the central bank. The President lost the power to appoint mayors in 1986, and governors in 1991, which in practice ended the dominant role over the career paths of regional political leaders. ${ }^{22}$ Incidentally, mayors and governors operate more as agents of legislators, rather than the opposite, which is the case of countries like Argentina and Brazil. There are, of course, important exceptions, like the majors and governors of the largest cities and departments.

This means that the President lost a bargaining chip in negotiating with both national and regional leaders. Also, presidential reelection was permanently banned by the 1991 Constitution; prior to 1991 presidents could run again, although not for consecutive terms. However, at the end of 2004 Congress approved a constitutional reform allowing presidents to be reelected for consecutive terms.

\section{Reactive Powers}

The President can veto legislation, on procedural and substantive grounds. However, Congress can override the executive's veto with a simple majority. Before 1991, it was much harder to overrule a presidential veto because a two-thirds majority was required.

21 Before 1945 there were six mandatory debates.

\section{Electoral Rules}

Finally, a majority runoff electoral rule replaced the plurality rule. ${ }^{23}$ The majority runoff, along with the timing of congressional elections (which take place before the first round presidential election), have changed the patterns of coalition building. After 1991, we observe a clear pattern of post-electoral coalitions, especially in Samper and Pastrana's terms, and a greater role of legislators in the election of the President, especially due to the proximity of these elections. President Uribe Vélez, running in 2002 on an independent platform, was the first candidate to obtain more than 50 percent of the votes in the first round in the three presidential elections since the introduction of the second round. The average share of the votes obtained in the first round in the 1994 and 1998 presidential elections was 40.39 percent, in contrast to 51.01 percent in the 1978, 1982, 1986, and 1990 elections.

\section{B. Congress}

The Colombian Congress can be classified as reactive more than proactive, given its lack of organization and resources and the substantial legislative

22 Since 1986, municipalities (currently 1,069) elect their majors, and (since 1991) departments (now 33) elect their governors for single three-year terms (extended to four years after 2003). Previously, the President had the right to appoint and dismiss all governors and mayors. Political decentralization as well as fiscal decentralization has increased the influence of majors and governors, although not to the point observed in Argentina and Brazil. Governors and mayors (with few notable exceptions) do not play a key role in national politics. They are highly dependent on the national budget, especially for public investment funds.

23 Payne, Adserà and Boix (2003, p. 486) argue that the abandonment of the plurality formula was motivated by partisan power strategies, such as preventing a third, minority party from obtaining the presidency. Others argue that this was a strategy by the Conservative Party to take advantage of factionalism within the Liberal Party. 
powers of the executive. ${ }^{24}$ A powerful executive, combined with an extremely personalistic electoral system, implicitly delegates the national agenda to the President and the cabinet members. Nonetheless, the legislature has always been an important veto player for the President, especially in areas where the executive does not have complete jurisdiction. The symmetric two-chamber Colombian Congress is one of the oldest in Latin America. Several changes, however, have affected size, constituencies, and tenure. One such reform was the introduction of directly elected senators in 1930 (previously indirectly elected by departmental assemblies). ${ }^{25}$ Members of the Senate were more prominent leaders in Congress, mainly because they had four-year terms, compared to two-year terms for members of the House (extended to four years by the 1968 reform).

The 1991 reform reduced the number of representatives to 165 from 199, and the number of senators to 102 from $113 .{ }^{26} \mathrm{Also}$, the reform transformed the national territories (large portions of the territory with low population density) into departamentos and established a minimum representation of two House members per departamento. Thus, seven districts achieved representation in the House for the first time. Since 1991, Senators have been elected in national, rather than departmental, constituencies.

\section{Electoral Rules}

As shown in Figure 4, congressional elections have become increasingly contested, especially after 1991. The rapid growth in the number of lists competing in congressional elections has also implied that a large number of successful lists elect only one legislator (Figure 5). For example, in 2002 only 3

24 See Payne (1968, p. 246) for a rough description of the lack of resources of the Colombian Congress.
Figure 4. NUMBER OF LISTS RUNNING PER ELECTION (1958-2002)

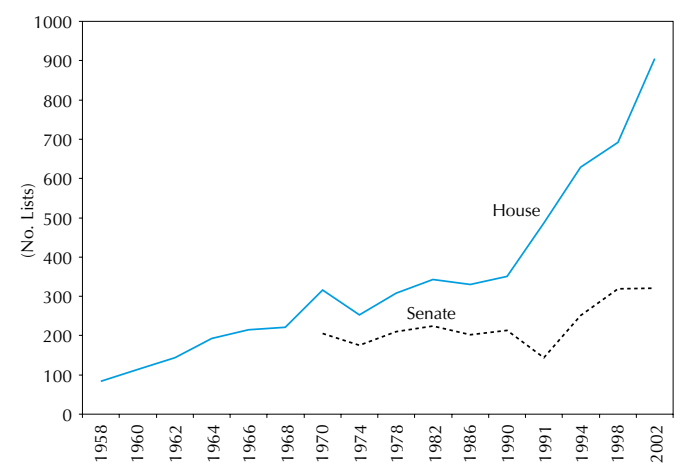

Source: Pizarro, E. (2001).

Figure 5. PERCENTAGE OF WINNING LISTS THAT ELECT ONLY ONE CANDIDATE (1974-2002)

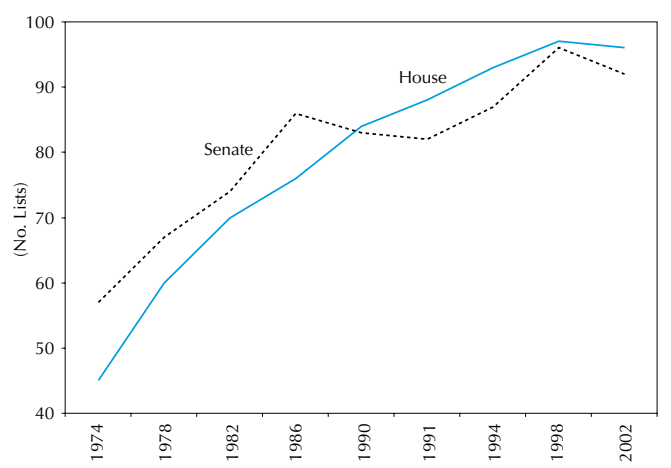

Source: Archer \& Shugart, 1997 (1974-1990) and Registraduría Nacional del Estado Civil.

25 Previously, legislators were not remunerated and the system of specialized committees had not been adopted. In 1945, the two chambers adopted common rules of procedure. That year, the number of readings for the bills was reduced from six to four, enhancing the role of specialized committees (see Pachón Buitrago, 2004).

26 Currently the House has 165 members, including four from special districts (two from indigenous communities, two from black communities and one from Colombians living abroad). The Senate has 102 members, two of them elected from the special indigenous districts. 
lists, out of more than 300, rendered more than one senator. To a large extent this has been the result of the electoral rules that have been used during the last 40 years, which were not changed by the 1991 Constitution. In fact, according to the formula of largest remainders (LR) or Hare system, seat quotas are calculated by dividing the number of votes by the number of seats. Seats are first allocated to lists that surpass the quota. The remaining seats are then allocated to the largest remainders, generating incentives for parties to fragment into factions. To illustrate the point, take the case of a district with 1,000 voters and 10 seats, so the quota is 100 . Party A has 650 votes, B has 240, C has 70 and D has 40. Accordingly, party A would get 7 seats ( 6 by quota, 1 by remainder), B would get 2 (by quota), $C$ would get 1 (by reminder), and $\mathrm{D}$ none. Now, if $\mathrm{B}$ subdivides into 3 factions it will get 3 seats (all by remainder) taking one away from party $A$, who gets 6 . Party $C$ does not benefit from fragmenting, however, showing that this strategy is only beneficial for parties that are large enough to get at least one seat allocated by quota (in fact, if $\mathrm{C}$ splits into two equal parts, it gets nothing). Now, if party A splits into 8 factions, and party B into 3, they will capture all seats ( 8 and 2 , respectively).

The key point, as mentioned by Payne, Adserà and Boix (2003), is that the largest remainder formula is applied in each district to factional lists rather than party lists. The electoral law allows multiple factions to present lists under the same party label. Thus, though the factional lists are closed and blocked, in effect the system can be considered to operate with unblocked party lists. The result is that parties have increased the number of lists over time, maximizing their seat share, while enhancing its decentralization and factionalization. ${ }^{27}$

27 See Roland and Zapata (2005) for the implications of the electoral rules.
As a result, most seats are allocated by the residual system. In 1998, only 5 percent of senators were elected by quota, and all others by remainder. The marginal price of a seat, calculated as the minimum remainder for which a seat was allocated, represents roughly only 40 percent of the number of votes specified by the quota, and it was lower in 1998 than in 1991 and 1994. As a result, some elected senators represent less than 0.1 percent of Colombia's population. ${ }^{28}$ The 1991 reform did not change this situation, mainly because no representation thresholds were put in place to discourage small lists. The LR-Hare system remained in place, encouraging fragmentation and election by largest remainders. ${ }^{29}$

Instead of achieving what Haggard and McCubbins call "unity of purpose" by having more urban representation and dispersed constituencies, the national constituency for the Senate furthered the political fragmentation. Rather than gathering votes across districts as initially intended by the reform, seats are gained mostly by obtaining regionally concentrated votes. Thus, senators are still inclined to advance policies that produce regional or sector-specific benefits, making it hard for the government to push policies that resemble public goods. Furthermore, as discussed below, state campaign funding is given directly to the candidates, creating additional incentives to form factions or movements, instead of depending on "national party" resources.

The combination of the incentives created by the electoral system and by campaign funding has resulted in a large number or movements that are essentiaIly electoral machines. For example, 72 movements

\footnotetext{
28 See Botero (1998) and Rodríguez-Raga (2001).

29 In a way, this system is diametrically opposite to that of Chile, where, if coalitions do not come together, they do not reach the one-third threshold, and they do not win any seats.
} 
obtained at least one seat in the House of Representatives in the 2002 election. ${ }^{30}$ Although these movements are typically affiliated with a major party, the excessive fragmentation of legislators is a key characteristic of Congress, with an important impact on the policymaking process.

\section{Organization}

Each chamber is organized into seven (eight before the 1991 reform) Comisiones, which have a significant role in the workings of Congress (see Table 2). Since 1945, legislators can only belong to one permanent committee and have to remain on that committee for their entire four-year term; committee membership is determined by elections. Each legislator has one vote and needs a certain number of votes in order to get into a particular committee. Committees dealing with constitutional and economic-budgetary matters, require more votes than the rest. To facilitate coordination, each party names a compromisario (delegate) in order to nominate legislators of that party to the different committees, taking into account seniority, specialty, and popularity of the legislator.
Party membership is indispensable in order to access the committee of first preference (Pachón Buitrago, 2003). This is important because it shows that behind a veil of fragmentation and atomization, party structures play a role in organizing legislative activity. We will see more evidence in this direction in the discussion of political parties below.

Exclusive committee membership contrasts with other Latin American congresses where legislators belong to various permanent committees and hence do not have an incentive to specialize. The Colombian Congress also has a small number of standing committees, which are entrenched in the constitution, compared to the Mexican or Argentinean legislatures, which have more than 35 standing committees with overlapping jurisdictions. This means that the rules of the game are stable since there is only one route for the introduction of legislation. The only choice in the hands of the executive is the starting point, which can be the House or the Senate. Plenary sessions rely heavily on what is approved by the committees, especially in economic and budget matters. Membership in the Economic and Budget

\section{Table 2. DESCRIPTION OF COMMITTEES' JURISDICTION}

\section{Committees Jurisdiction}

Committee $1 \quad$ Constitutional Reforms, Statutory Laws, District Organization, Peace Strategies

Committee $2 \quad$ International Relations, National Security and Defense, Treaties, Diplomacy Issues

Committee 3 Treasury, Taxation, Subsidies

Committee $4 \quad$ Organic Budget Law, Financial System Control, Sale of National Assets

Committee $5 \quad$ Agriculture Regime, Ecology, Environmental Issues, and Regional Development Agencies

Committee 6 Mass Media, Communication, Public Emergencies, Public Services, Transport, and Public Works

Committee $7 \quad$ Public Service Regime, Union Organizations, Societies, Social Securities

Source: Congreso de la República de Colombia.

30 The only requirement to form a political party is to present 50,000 valid signatures. As a result, most legislators form their own "movement", appearing on the ballot with a different party label than the traditional party to which they belong. 
Committees is highly valued because of proximity to government funds. The committee in charge of constitutional and political affairs is also highly visible, with highly valued membership.

As a consequence of growing professionalization, incumbency rates have been steadily higher since the 1930s. As shown in Figure 6, the incumbency rate has increased to 50 percent in the last decade, compared to 10 percent in 1935. Nonetheless, and possibly as a result of greater fragmentation, incumbency rates have fallen in both the House and Senate since the 1991 constitutional reform. Still, when compared to other Latin American countries, Colombia has one of the highest incumbency rates. ${ }^{31}$

Certainly, there are members of Congress who have a long tenure, and are considered to be "professional legislators", characterized by what has come to be known in the literature as "static" ambition (Samuels, 2003). However, the "amateur legislator" with "progressive" ambition is not unheard of in the Colom-

\section{Figure 6. REELECTION RATE IN CONGRESS}

(1935-1998)

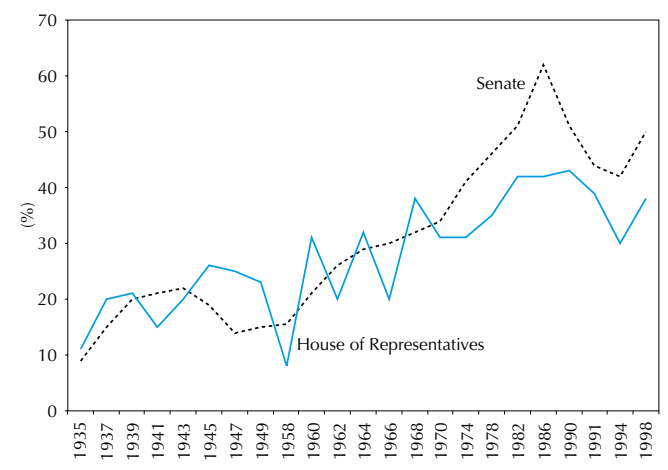

Source: Archer, Ronald (1995).

31 According to Pachón Buitrago (2004), the reelection rates of Argentina and Brazil are 17 percent and 45 percent, respectively. bian Congress, where legislators sometimes do not run for reelection or simply seek other political offices. We argue that certain committees (e.g., constitutional, economic and budgetary) offer legislators an incumbency advantage as well as a higher level of professionalization in comparison to other committees. As a result, members of those committees are the natural leaders of Congress. Using data from 1970 to 1998 , Figure 7 show that the incumbency rates for members of these committees are higher than for other legislators. Professionalization thus seems to provide an advantage to incumbents.

\section{Figure 7. INCUMBENCY RATE FOR COMMITTEES OF HOUSE AND SENATE (1970-1998)}
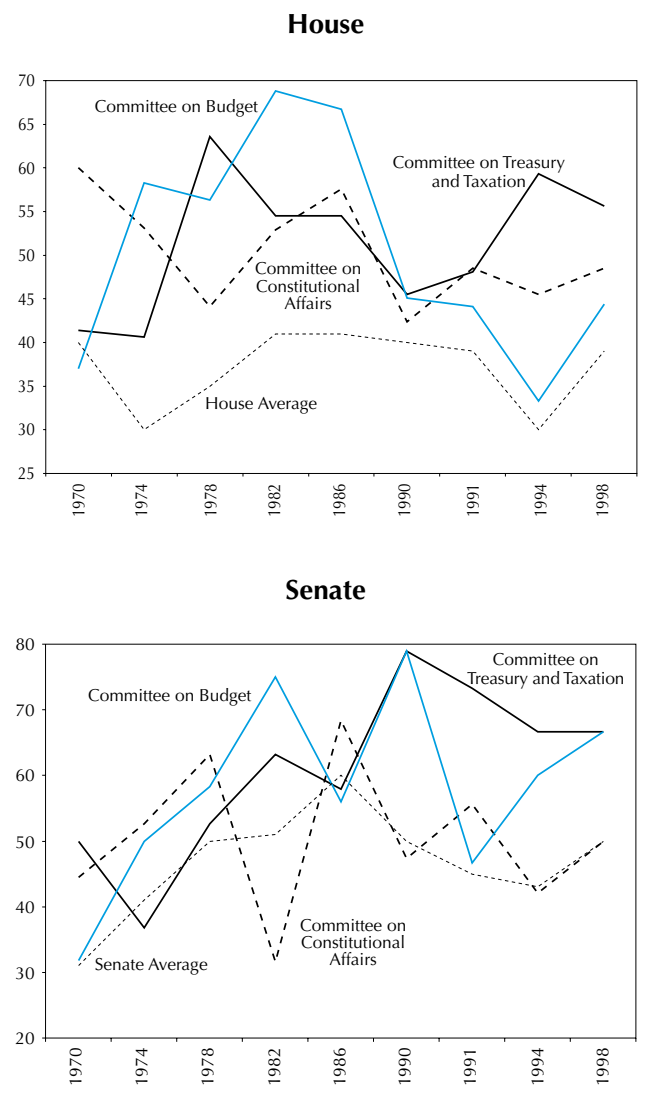

Source: Authors' calculations - Data from Gacetas del Congreso. 


\section{Political Parties}

The Colombian party system dates from the early years of the republic and is considered one of the oldest and most institutionalized in Latin America (Mainwaring and Scully, 1995). The system has been dominated by two strong parties, Liberal and Conservative, and high polarization between them has often resulted in conflict and violence. The last such episode-and one of the worst- ended with the Frente Nacional pact in 1958 which, as mentioned above, established a strict parity between the two parties.

Even before the Frente Nacional, the party system was characterized by high intra-party competition, functional party coalitions in Congress, and significant party discipline in presidential elections. Although intra-party competition was always part of Colombia's political history, lack of vote pooling since $1974,{ }^{32}$ political decentralization since the early 1980s, and the 1991 constitutional reform brought it to new levels. In the last 15 years, small parties and movements have proliferated. ${ }^{33}$ The existence of high intra-party competition weakened political leadership, ultimately fragmenting party organizations and undermining the traditional twoparty system. ${ }^{34}$ Although there are still no conclusive

\footnotetext{
32 Before 1974, parties pooled votes across lists within the parties. If a list had less than half the electoral quotient, the votes from this list would be transferred to the list with the most votes. See Pachón Buitrago (2004) on the consequences of the lack of vote pooling in Colombia since 1974.

33 Gutiérrez (2003) suggests that the proliferation of lists is controlled by the party.

34 Gutiérrez (1999 and 2001) argues that the internal structures of the traditional parties have changed but have not been destroyed. The value of the party label is still an important asset for politicians, although the linkage among the different levels of government has a more horizontal character where it is difficult to impose sanctions.
}

answers about the effects of decentralization on the party structure, one of the most discussed effects has been the fragmentation of the party system (Pizarro 1995; Archer and Shugart, 1997; Neilson and Shugart, 1999; Fajardo, Moreno and Shugart, 2004; Rodríguez-Raga 1999, 2001). The degree of fragmentation has increased largely because regional and local political machines do not require centralized political parties, and parties no longer have the means to control the career paths of their local leaders in the local areas.

To make politics even more candidate-based, the 1991 Constitution incorporated a system of direct public funding for congressional and presidential campaigns, where the political movement rather than the party is the recipient of the funds. At the same time, the constitution confirmed the independent electoral authority (Consejo Nacional Electoral), in charge of elaborating and distributing the ballot (tarjetón) with the name and picture of all aspiring candidates. Before 1986, candidates were responsible for handing out their lists on pieces of paper (called papeletas) that were used to cast a vote, and party infrastructure was useful for the distribution of papeletas among voters. Currently, there is less value to those logistical capabilities. These reforms not only allowed new cleavages to run for elections, but also lowered the costs of leaving traditional parties and their central directorates. ${ }^{35}$

This, of course, has to be analyzed in conjunction with the increased availability of public expenditures at the local level as a result of fiscal decentralization, as legislators are increasingly independent from the parties and from the national government.

\footnotetext{
35 In 1998, 67 parties and movements were legally recognized by the electoral authorities receiving state funds. See PosadaCarbó (2001).
} 
However, as mentioned above, the internal rules of Congress enhance the role of the parties and recentralize power in a few hands. Parties are determinant for accession to specific Committee membership, hierarchical positions (presidents and vice-presidents of the Senate, House, and their respective committees), and strategic roles (sponsorship of key bills). The President of the committee appoints one or several sponsors for each bill. Sponsors, in turn, have a decisive role in the legislative process. On key bills initiated by the executive, sponsors have considerable bargaining power. They are very influential in what is finally approved on the floor and act as political brokers between the executive and other legislators. The relative position in this hierarchy (President of the chamber, President of the committee, and sponsor) determines the amount of "pork" that a legislator receives, in the form of positions in the national government bureaucracy and funds for investment projects. ${ }^{36}$ As shown in Figure 8, the number of sponsors per bill has been increasing rapidly since 1991 . As we will show below, a bill with more sponsors has greater chances of success. ${ }^{37}$

These privileges are distributed according to partisan criteria, and thus, legislators organize procedural coalitions in order to secure them (see Carroll, Cox and Pachón, 2004). As a result, post-electoral party coalitions are the norm rather than the exception. A good example is the organization of the inde-

\footnotetext{
36 Unfortunately there are no data to support this point, but legislators euphemistically speak of platinum, gold, silver and regular status depending on where they rank.

37 An interesting trend is seen when the government calls the joint economic committees (House and Senate) to discuss a bill in which the executive has special interest. In this case the probability of success is much higher (on average 75 percent of the bills are approved). The cost, however, is explosion in the number of sponsors. The only bill submitted to the joint economic committees in 2003 had 36 sponsors.
}

Figure 8. AVERAGE NUMBER OF SPONSORS

(1982-2003)

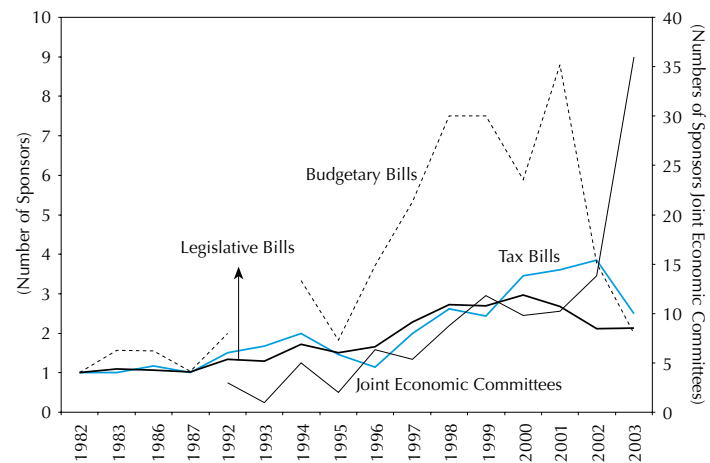

Source: Authors' calculations.

pendents into the Polo Democrático. Before 1998, independents held 25 percent of congressional seats but had no representation in any valuable position in Congress. After forming a coalition for the 2002 elections they have been able to secure strategic positions. Thus, although the structure of parties in Congress can be described as horizontal, the internal rules of Congress provide a temporal hierarchical structure that also improves their bargaining power vis-à-vis the executive. ${ }^{38}$ In other words, parties solve collective action problems within Congress.

Finally, Figure 9 shows the Laakso-Taagepera index of Effective Number of Parties (ENPP), which is a measure of fragmentation, calculated as the inverse of the sum of squared party shares for each legislative election. ${ }^{39}$ The ENPP has increased from two political parties in the 1970s (Liberal and Conservative), to three in the post-1991 period (Liberals, Conservati-

\footnotetext{
38 There was a constitutional reform in 2003 in which Congress approved the change of the electoral system, changing the Hare quota to the D'Hondt quota, as well as an open list system for all councils, assemblies and the national Congress. The first election with the new system took in 2006 at the national level. At the regional level, the first election took place in 2003. For an explanation for the reform, see Fajardo, Moreno and Shugart (2004).
} 
Figure 9. LAAKSO-TAAGEPERA INDEX OF EFFECTIVE NUMBER OF POLITICAL PARTIES IN THE HOUSE OF REPRESENTATIVES (1974-2002)

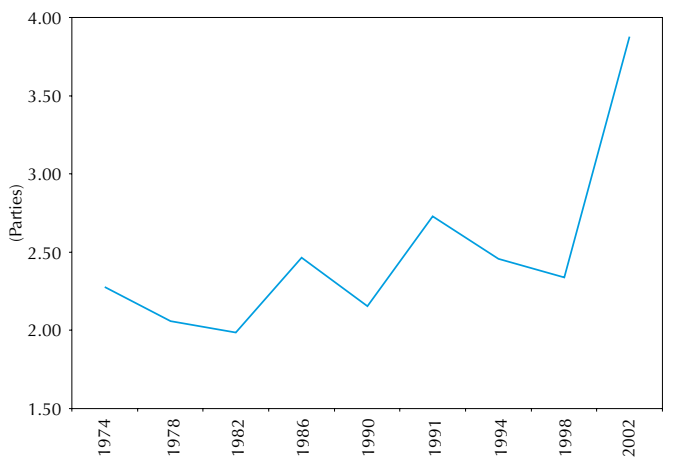

Source: Authors' calculations - Data from Registraduría Nacional del Estado Civil.

ves, and the AD-M19), to four in 2002: Liberal (official), Liberal (uribistas), Conservative, and the Polo Democrático centerleft coalition, which includes the AD-M19.

\section{Courts}

In the Colombian system of separation of powers, the judiciary has always been a key player in the policymaking process. Since the 1886 Constitution, the

$39 E N P P=\left(\Sigma s_{i}^{2}\right)^{-1}$, where $s$ is the seat share of party $i$ in the legislature. We calculated it by adding movements because the traditional parties endorse these movements and count them as party members. For example, Senator Roberto Gerlein, who has been a Conservative leader in Congress for decades, runs under the label Movimiento Nacional and not with the one of the Partido Nacional Conservador. The same is true for Senator Jose Raúl Rueda, also a Conservative, who runs under the label Movimiento Político Ciudadanos por Boyacá. However, they vote together and are part of the Conservative coalition for procedural elections within Congress. The same happens with the independents who run under different movement labels but behave as a coalition once in Congress (M-19, Movimiento Visionario, ANAPO, etc.) Currently, there exist more than 70 party labels that are recognized by the Registraduría Nacional del Estado Civil. Thus, it makes more sense to count them together even if they run on apparently different party labels. The information about these coalitions for the Conservative Party is in Pachón Buitrago (2002), and in the reports by Congreso Visible at www.cvisible.uniandes.edu.co.
Supreme Court has been in charge of constitutional review and dispute settlement between the executive and Congress (for instance after a presidential veto on the grounds of unconstitutionality). The Supreme Court also reviewed ex officio all decrees issued by the executive during a state of siege or state of economic emergency. According to Cepeda (2005), between 1886 and 1991, of a total of 2,496 rulings of constitutional review, 1,489 (that is 60 percent) were related to decrees issued by the executive during periods of exceptional legislative power. Of the latter, only 25 percent were found unconstitutional. Due to the constant use of extraordinary powers by the executive, the Supreme Court became the last resort for very controversial and difficult decisions. One of the most remembered is the ruling that declared unconstitutional the Extradition Treaty in 1986, after drug-traffickers threatened justices. ${ }^{40}$ Before 1991, although the Supreme Court was active in terms of judicial review (probably more than other Latin American courts), with some important and notable exceptions its rulings focused more on formal review of the procedures and less on the content of the bills. ${ }^{41}$ Without a doubt, the appointment mechanism, as well as strict bipartisan parity, restricted the independence of the judicial defense of the constitution.

After the major reforms of 1991, the key player became the cc. The nomination procedure changed radically, as part of an explicit attempt to make the judiciary more independent from the government. Nine magistrates are elected by the Senate from lists presented by the President, Supreme Court, and Consejo de Estado, for periods of eight years without the

\footnotetext{
40 See Arrieta (1991).

41 See Sarmiento y Buitrago (1985) and Cepeda (2005) for an account of some interesting exceptions where the Supreme Court opposed the government on important matters such as constitutional reform, tax initiatives, and extradition.
} 
possibility of reelection. ${ }^{42}$ Instead of an abstract a posteriori review of the law, the new system is based on abstract ex officio and ex ante review of the most important statutes, treaties and bills. In addition, the cc revises ex officio the declaration of any state of emergency by the executive as well as the decrees issued under such status. Although ex post judicial review had been in the judicial system since 1904, the amount of bills that are reviewed each year has increased monumentally in the last 10 years. In fact, since 1991 the cc has issued 2,923 rulings on abstract constitutional review, more than the Supreme in Court in 105 years. The majority of these rulings result from citizens' use of the Acción Pública de Inconstitucionalidad. In 27 percent of the cases the cc has ruled the reviewed laws or decrees (or aspects of them) unconstitutional. Between 1992 and 2002, a total of 141 rulings corresponded to the constitutional revision of decisions taken by the executive under special legislative power. The relative y small number (less than 5 percent of the total rulings on constitutional review) is indicative of the restrictions imposed by the constitution on the use of these powers by the executive. Moreover, 35 percent of the legislative decrees were found unconstitutional, while the constitutionality of another 4 percent was conditioned by the cc.

Although in theory the cc is expected to have negative legislative power, in practice it exercises great influence over policymaking. The main reason is that the many policy issues have been elevated to the constitutional rank, especially after the constitutional revision of laws. This has been the case of public sector wages, mortgage interest rates, and pensions, among others. In practice, this implies that constitutional reforms are necessary to change policies in

42 Rosenthal and Kugler (2005) provide a detailed account of the workings of the judicial branch. certain areas, and even then, reforms are subject to the constitutional revision. A good example is the 2003 referendum that was required in order to freeze government salaries. Given the legislative procedure that a constitutional reform entails, transactions costs are now higher and the cc has a larger jurisdiction.

\section{E. Technocracy}

Long before John Williamson in his writings on the Washington Consensus coined the term "technopols" to describe the key role played by us and uK graduate-trained economists in the policymaking process in Latin America, in Colombia, since the early 1960s "technocrats" was the term used for this new breed of bureaucrats.

Technocrats made their first appearance in Colombia as a result of the creation of the Monetary board in 1963 and the powerful National Planning Department, which became the landing place for the newly graduated foreigntrained economists. With rare exceptions, the head of the Planning Department (a cabinet level position) has been a Ph.D. economist with recognition in academic circles. The role of the technocracy as a key player in the PMP scene was strengthened under the Lleras Administration in 1966-1970. The President made wide use of the CONPES (Consejo de Política Económica y Social) as a vehicle to formulate policies, based on documents prepared by the Planning Department. Moreover, the implementation of those policies was often delegated to the technocrats, above the mandate of cabinet members.

The role of the technocracy achieved a high point during the López Administration (1974-1978). Not only the powers of the Monetary board advisors and the Planning Department were enhanced, but for the first time a foreign-trained economist was appointed as Finance Minister. All significant posts 
at the ministry were assigned to technocrats (some of them becoming Ministers of Finance years later). More importantly, the leadership in the economic PMP was transferred completely to the Finance Minister, and, notwithstanding some exceptional periods, it has become a norm that Finance Ministers are chosen among professionally trained economists, most of them with graduate training in top foreign universities.

Another high point in delegation of policymaking powers to technocrats was reached during the administration of César Gaviria (himself a professional economist and former Finance Minister). The major step in this direction was the delegation of monetary policy to an independent board, which has become a stronghold of the technocracy. Besides this decision, it does not seem that there has been any enhancement in the role of technocrats in the PMP resulting from the 1991 Constitution.

Although technocrats have on occasions been appointed to other ministries, their influence has been much less important than in the economic policy arena. The career path of technocrats often involves academic work at independent institutions such as FEDESARROlLo and the Universidad de los Andes, or international organizations. Very few have embarked on successful political careers.

\section{A CHARACTERIZATION OF THE POLICYMA- KING PROCESSES (PMPS)}

\section{A. Before the 1991 Constitution}

During the Frente Nacional period (1958-1974), the rules of the political game constrained the role of Congress in economic policy and enhanced the decision-making capacity of the government. ${ }^{43}$ In practice, this restricted the policy options and faci- litated the adoption of consensual macroeconomic policies. ${ }^{44}$ There is no evidence of major macro policy reversals, while at the same time policies were rapidly adjusted in light of external conditions.

Presidents had a free hand to implement policy, even in the hypothetical absence of majorities in Congress. As documented by Hartlyn (1981), the executive faced some opposition in Congress during the Frente Nacional. Some factions opposed on ideological grounds, such as the MRL and ANAPO, and others for more ephemeral or specific reasons. Nevertheless, ample majorities were always secured, and presidents had leverage to pass their bills. Opposition was highest during the Misael Pastrana Administration (1970-1974), but even then it did not exceed 33 percent of Congress (see Table 3 ).

Cabinet and gubernatorial appointments were critical in the coalition-building process. The appointment of a prominent political leader in Congress (typically a regional party boss) to the cabinet or a governorship was the most effective way of securing the coalition. Presidents had the difficult task of implementing the "milimetría", so cabinets and governorships had to have adequate representation by regions and political factions. In the case of cabinets, Table 4 shows the political affiliations of all ministers since 1970 at the beginning of each administration as well as two years later (halfway into the term). Most presidents introduced significant changes at mid-term, several of them (e.g., Turbay, Barco and Samper) widening the representation of political groups. ${ }^{45}$ Normally, the Liberal Party has lost some

\footnotetext{
43 Congress was not totally excluded from economic policymaking. Tax reforms formally were always in its hands, although governments used the state of economic emergency to bypass legislative discussion.

44 See Hoskin, Leal and Kline (1976) and Hartlyn (1981).
} 
Table 3. PARTIES AND FACTIONS IN CONGRESS DURING THE FRENTE NACIONAL

\begin{tabular}{|c|c|c|c|c|c|c|c|c|}
\hline \multirow[t]{2}{*}{ Presidential Period } & \multicolumn{2}{|c|}{$\begin{array}{c}\text { Alberto Lleras C. } \\
(1958-1962) \\
(\%)\end{array}$} & \multicolumn{2}{|c|}{$\begin{array}{c}\text { Guillermo Valencia M. } \\
(1962-1966) \\
(\%)\end{array}$} & \multicolumn{2}{|c|}{$\begin{array}{c}\text { Carlos Lleras R. } \\
(1966-1970) \\
(\%)\end{array}$} & \multirow{2}{*}{$\begin{array}{c}\begin{array}{c}\text { Misael Pastrana B. } \\
(1970-1974) \\
(\%)\end{array} \\
1970\end{array}$} & \multirow{2}{*}{$\begin{array}{c}\begin{array}{c}\text { Alfonso López M } \\
(1974-1978) \\
(\%)\end{array} \\
1974\end{array}$} \\
\hline & 1958 & 1960 & 1962 & 1964 & 1966 & 1968 & & \\
\hline \multicolumn{9}{|l|}{ Pro-government } \\
\hline \multicolumn{9}{|l|}{ Liberal Party } \\
\hline Oficialistas & 50 & 38 & 32 & 32 & 36 & 38 & 27 & 57 \\
\hline \multicolumn{9}{|l|}{ Conservative Party } \\
\hline Laureanista faction & 33 & - & - & - & - & - & - & - \\
\hline Ospinista faction & - & 24 & 27 & 35 & 18 & 24 & 14 & - \\
\hline Sub total & 83 & 62 & 59 & 67 & 54 & 62 & 41 & 90 \\
\hline \multicolumn{9}{|l|}{ Disidents } \\
\hline \multicolumn{9}{|l|}{ Liberal Party } \\
\hline Belisarista faction & - & - & - & - & - & - & 2 & - \\
\hline Sourdistas and other & - & - & - & - & - & 8 & 7 & - \\
\hline \multicolumn{9}{|l|}{ Conservative Party } \\
\hline Laureanista faction & - & - & - & - & - & - & - & - \\
\hline Alvarista faction & - & 25 & 25 & - & 14 & 10 & - & - \\
\hline Ospinista faction & 13 & - & - & - & - & - & - & - \\
\hline Sourdista faction & - & - & - & - & - & - & 6 & - \\
\hline Belisarista faction & - & - & - & - & - & - & 9 & - \\
\hline Sub total & 13 & 25 & 20 & 0 & 14 & 18 & 25 & 0 \\
\hline \multicolumn{9}{|l|}{ Anti-National Front } \\
\hline \multicolumn{9}{|l|}{ Liberal Party } \\
\hline MRL & - & 12 & 18 & 17 & 11 & 1 & - & - \\
\hline ANAPO & - & - & - & 0.50 & 2 & 3 & 13 & - \\
\hline \multicolumn{9}{|l|}{ Conservative Party } \\
\hline Alzatistas o Leyvistas & 4 & 0.60 & - & 0.50 & 0.50 & - & - & - \\
\hline ANAPO & - & - & 3 & 14 & 17 & 14 & 20 & 7 \\
\hline Sub total & 4 & 13 & 21 & 32 & 30 & 18 & 33 & 7 \\
\hline Total & 100 & 100 & 100 & 100 & 100 & 100 & 100 & 98 \\
\hline Seats & 148 & 152 & 184 & 184 & 190 & 204 & 210 & 199 \\
\hline
\end{tabular}

Source: Hartlyn (1981). PhD Dissertation - Yale University.

representation in the cabinet during the second half, while the technocracy has been more important in administrations with greater command of the majorities in Congress (Barco, López, and Gaviria). At the level of movements, the pastranista wing of the Conservative Party has gained representation

45 This does not imply that the effective number of parties in the Cabinet (measured as in footnote 39) increased during the second half of the administration. during the second half of administrations, while the participation of the left has been minimal.

The rules of the political game imbued the Minister of Finance with immense power. As mentioned in the previous section, traditionally the Minister of Finance was not a politician, but almost always a professional economist. As Urrutia (1996) argues, both Liberal and Conservative politicians would rather have a technocrat occupy this ministry than a 
Table 4. PRESIDENT'S CABINET BY POLITICAL PARTIES 1970-2004

(Percentage)

\begin{tabular}{|c|c|c|c|c|c|c|c|c|c|c|}
\hline & \multicolumn{2}{|c|}{$\begin{array}{c}\text { Misael Pastrana B. } \\
1970-1974\end{array}$} & \multicolumn{2}{|c|}{$\begin{array}{c}\text { Alfonso López M. }^{\mathrm{a}} \\
\text { 1974-1978 }\end{array}$} & \multicolumn{2}{|c|}{$\begin{array}{c}\text { Julio César Turbay A. } \\
\text { 1978-1982 }\end{array}$} & \multicolumn{2}{|c|}{$\begin{array}{c}\text { Belisario Betancur C. } \\
1982-1986\end{array}$} & \multicolumn{2}{|c|}{$\begin{array}{c}\text { Virgilio Barco V. } \\
1986-1990\end{array}$} \\
\hline & Initial & Mid-term & Initial & Mid-term & Initial & Mid-term & Initial & Mid-term & Initial & Mid-term \\
\hline Liberal(Official line) & 38 & 46 & 46 & 54 & 54 & 46 & 31 & 31 & 85 & 62 \\
\hline Other Liberal Groups & 8 & - & - & - & - & - & 23 & 8 & - & 15 \\
\hline Military/ Technocracy & 8 & 8 & 15 & 15 & 8 & 8 & 8 & 8 & 15 & 23 \\
\hline Conservative (Alvarista/MSN/Official line) & 15 & 15 & 31 & 15 & 23 & 23 & 15 & 15 & - & - \\
\hline Conservative (Ospinistas/Pastranistas) & 31 & 31 & 8 & 15 & 15 & 23 & 23 & 38 & - & - \\
\hline ANAPO/ADM19/Syndicalism/Polo & - & - & - & - & - & - & - & - & - & - \\
\hline Effective number of parties & 3.60 & 2.96 & 2.96 & 2.77 & 2.68 & 3.07 & 4.33 & 3.60 & 1.35 & 2.19 \\
\hline Total number of ministers during term & 28 & & 33 & & 29 & & 41 & & 47 & \\
\hline \multirow[t]{3}{*}{ Average number of ministers per ministry } & 2.15 & & 2.54 & & 2.23 & & 3.15 & & 3.62 & \\
\hline & \multicolumn{2}{|c|}{$\begin{array}{c}\text { César Gaviria T. }^{c} \\
\text { 1990-1994 }\end{array}$} & \multicolumn{2}{|c|}{$\begin{array}{c}\text { Ernesto Samper P. } \\
1994-1998\end{array}$} & \multicolumn{2}{|c|}{$\begin{array}{c}\text { Andrés Pastrana A. } \\
\text { 1998-2002 }\end{array}$} & \multicolumn{2}{|c|}{$\begin{array}{l}\text { Álvaro Uribe V. }^{\mathrm{d}} \\
\text { 2002-2006 }\end{array}$} & & \\
\hline & Initial & Mid-term & Initial & Mid-term & Initial & Mid-term & Initial & Mid-term & & \\
\hline Liberal(Official line) & 38 & 29 & 67 & 60 & 19 & 6 & 8 & 8 & & \\
\hline Other Liberal Groups & - & 36 & 7 & 13 & 19 & 25 & 77 & 77 & & \\
\hline Military/ Technocracy & 15 & 14 & - & - & 13 & 13 & - & 8 & & \\
\hline Conservative (Alvarista/MSN/Official line) & 23 & 7 & 27 & 20 & 13 & 6 & 15 & 8 & & \\
\hline Conservative (Ospinistas/Pastranista) & - & 14 & - & - & 38 & 44 & - & - & & \\
\hline ANAPO/ADM19/Syndicalism/Polo & 8 & - & - & 7 & - & 6 & - & - & & \\
\hline Effective number of parties & 3.93 & 3.92 & 1.92 & 2.37 & 4.13 & 3.56 & 1.61 & 1.64 & & \\
\hline Total number of ministers during term & 37 & & 47 & & 39 & & 19 & & & \\
\hline Average number of ministers per ministry & 2.64 & & 3.13 & & 2.44 & & 1.46 & & & \\
\hline
\end{tabular}

Initial cabinet is according to the decree on the inauguration's day ( August 7th). Mid-term is cabinet two years later.

a Mid-term is October 19, 1976.

b Initial date is August 10, 1986 because three Conservative ministers were appointed on the date of the inauguration, but their party did not authorize.

c Mid-term is November 23, 1992. Noemí Sanín is considered as a representative of the official line of the Conservative Party, although she later became an independent and started her own movement.

d Mid-term is November 11, 2003.

Source: Authors' calculations.

potential rival. Other prominent actors in economic policymaking were the governor of the central bank and the manager of the Coffee Growers Federation. The very nature of the power-sharing agreement, as well as the usually long tenures of these key players, prevented opportunistic behavior and favored a long-term perspective in policymaking. ${ }^{46}$ The insulation of fiscal and monetary policies from political cycles, for example, was effective. ${ }^{47}$
Interest groups (e.g., gremios) had a very active role in the PMP during that period. The President, after

46 It is possible to argue that the long term perspective in economic policymaking predates both the Frente Nacional and the emergence of the technocracy. However, we will restrict the analysis to the period that starts in 1958.

47 See Escobar (1996) on the absence of political business cycles in Colombia. 
consultation with former presidents, along with representatives from the Church, the armed forces, and the parties' bosses, often invited the main private sector leaders for consultative sessions, in which important policy decisions were made, a tradition that is still regularly used today.

\section{B. After the 1991 Constitution}

The central implication of the 1991 Constitution for the PMP is that, although the President continues to initiate policies in the most relevant areas, Congress is increasingly involved in their discussion, oftentimes introducing significant changes. The gremios have lost importance as key actors, in part as a result of a more market-oriented economy. This clearly has been the case of the Coffee Growers Federation, although in this case the loss of power has been aggravated by its declining economic importance. Former presidents have also lost significant ground as key players and may not be considered veto players, in part due to the fragmentation of Congress and the relative loss of party discipline. ${ }^{48}$

Congress, on the other hand, has strengthened its position as a key player, enhancing its role in the policymaking process. Bypassing congressional discussion through the use of special powers was severely curtailed by the 1991 Constitution. In addition, the passage of legislation through Congress has become more complex as a result of the increase in the effective number of parties. However, as shown in Table 5, presidents elected after 1991 have been able to secure a majority coalition in Congress, regardless of their political affiliation. The PMP does not end with the enactment of legislation in Congress.

48 The 2003 referendum illustrates this well. Although former liberal Presidents unanimously supported the referendum, the Liberal Party officially opposed it.
The cc acquired the status of a key player and, on occasion, a veto player in the PMP. The constitutional revision of laws allows the cc to intervene in critical areas, such as fiscal policy.

The introduction of the cc's review has furthered the transaction costs for the executive, which can no longer rely on "short-term alignments" with Congress to enact its policy. Although the President still retains the exclusive right to introduce economic bills, the polity has become more resolute with the presence of the cc as a powerful veto gate. Even if the Executive can align its preferences with Congress, the CC imposes the greatest difficulty for the president's attempt to change the status quo.

Another prominent actor in the economic PMP is the central bank board, given its constitutional responsibilities as authority on monetary and foreign exchange matters. These two areas of policymaking have traditionally been considered highly specialized, and both Congress and the courts have had little involvement in their policy formulation. The significant change undertaken as a result of the constitutional change that granted independence to the central bank is the diminishing influence of the executive in monetary decisions, despite the presence of the Minister of Finance as President of the board.

The PMP since the mid-1990s has also been influenced by the u.s. government. While u.s. -Colombian relations have been traditionally amicable and supportive of each other's interests, the drug problem and domestic internal conflict- with potential regional repercussions- has put them on a new footing, as indicated by the approval of the u.s. -supported Plan Colombia in 1999. u.s. influence has also been felt through the backing of Colombian government economic programs, monitored by the IMF (since 1999). 
Table 5. FACTIONS AND LEGISLATIVE SUPPORT FOR PRESIDENTS ELECTED AFTER THE ENACTMENT OF THE 1991 CONSTITUTION (\%)

\begin{tabular}{|c|c|c|c|c|c|c|}
\hline \multirow[t]{2}{*}{ Presidential Period and Corresponding Party } & \multicolumn{2}{|c|}{$\begin{array}{l}\text { Ernesto Samper P. } \\
\text { Liberal Party } \\
1994 \text { - } 1998\end{array}$} & \multicolumn{2}{|c|}{$\begin{array}{c}\text { Andrés Pastrana A. } \\
\text { Nueva Alianza Democrática } \\
1998-2002\end{array}$} & \multicolumn{2}{|c|}{$\begin{array}{l}\text { Alvaro Uribe V. } \\
\text { Liberal dissident } \\
2002-2006\end{array}$} \\
\hline & Senate & House & Senate & House & Senate & House \\
\hline \multicolumn{7}{|l|}{ Pro-government } \\
\hline Liberal Party (National Directorate) & 57.84 & 56.17 & - & - & - & - \\
\hline Liberal Party (Colaboracionistas, Uribistas) & - & - & 20.59 & 27.95 & 29.41 & 36.14 \\
\hline Conservative Party & - & - & 27.45 & 32.30 & 29.41 & 28.92 \\
\hline Conservative Party (Lentejos) & 10.78 & 13.58 & - & - & - & - \\
\hline Independents (no traditional brand name) & - & - & 11.76 & - & 2.94 & - \\
\hline Government's majority & 57.84 & 56.17 & 59.80 & 60.25 & 61.76 & 65.06 \\
\hline Vote rejecting the accusation of the President ${ }^{\mathrm{a}}$ & 68.63 & 69.75 & & & & \\
\hline \multicolumn{7}{|l|}{ Dissidents (opposition) } \\
\hline Liberal Party (National Directorate) & 5.88 & - & 35.29 & 35.40 & 19.61 & 28.92 \\
\hline Conservative Party & 14.71 & 22.84 & - & - & - & - \\
\hline Independents (no traditional brand name) & - & - & - & - & 0.98 & - \\
\hline Total Opposition & 20.59 & 22.84 & 35.29 & 35.40 & 20.59 & 28.92 \\
\hline \multicolumn{7}{|l|}{ Independents } \\
\hline Liberal Party & - & - & - & 0.62 & - & - \\
\hline Conservative Party & - & - & - & - & - & - \\
\hline Independents (no traditional brand name) & 10.78 & 7.41 & 4.90 & 3.73 & 17.65 & 6.02 \\
\hline Total independents & 10.78 & 7.41 & 4.90 & 3.73 & 17.65 & 6.02 \\
\hline Total members & 102 & 162 & 102 & 161 & 102 & 166 \\
\hline Total lists introduced & 251 & 628 & 319 & 692 & 321 & 906 \\
\hline Lists per seat & 2.46 & 3.88 & 3.13 & 4.30 & 3.15 & 5.46 \\
\hline
\end{tabular}

a The process by which the President is formally acussed before the Senate requires a qualified majority and President Samper built a larger coalition with members of the Conservative Party who decided to support him.

Sources: Registraduría Nacional del Estado Civil, Revista Semana, Congreso Visible, www.senado.gov.co, and the House's legal office.

It is worth adding that, despite the well-known insecurity situation of the country, neither the armed forces nor the illegal groups have become veto players. The armed forces have been subordinate to and supportive of the country's civilian leadership. Presidents have replaced military commanders without hesitation when signs of unrest appear. Since the restoration of democracy in 1958, obedience to the President has never been an issue. On the other hand, the long-standing and militarily strong guerrilla movements in Colombia have not had a veto capacity, even during periods of peace negotiations. This is probably related to their negligible popular support.

\section{The Use of Pork and the PMPs}

Without doubt, budgetary allocations to specific projects promoted by the legislators are the main tool that governments have used in order to secure the approval of important bills. These allocations were called auxilios parlamentarios prior to 1991 . 
At one point they were subtly called obras útiles $y$ benéficas (useful and beneficial works). The degree of transparency of the allocations has also varied according to the political environment. For example, during the 1970s the auxilios took the form of scholarships to students chosen by legislators. The mechanics involved in their approval and distribution has been more or less the following: At the time of the submission of the Informe de Ponencia before the committees, the sponsors in charge of bills of interest for the government approach the Finance Minister to express their concerns for their own constituencies and to ask for an increase in the budget allocations for those regions. The size of the "pork," though not very transparent, varies with the relative importance of the project and the political support of the President. Nonetheless, the volume of auxilios has never been a major cause of fiscal imbalances. Though rules have changed, the distribution of the auxilios among regions and municipalities is closely related to the constituencies of key legislators in Congress.

The 1991 Constitution explicitly forbids the use of auxilios parlamentarios. In practice, however, governments and legislators have found ways of maintaining them, although in a more hidden and less formal fashion. Until then, the distribution of pork was accepted and legal, and in some way more transparent. It is well-known that since 1991 successive administrations have used other means, called cupos, to get the approval of key reforms. Rather than involving direct budget allocations to legislators, the system now favors the channeling of funds to investment projects at the level of municipalities and departments where legislators control the administration, or at the very least discuss with mayors and governors the final use given to these funds. Strictly speaking, these allocations are unconstitutional, but control agencies have turned a blind eye to this prac- tice. Moreover, several presidents have promised in their campaigns not to engage in these types of exchanges with Congress. In practice, however, it has been impossible to deal with Congress without the use of pork. The persistence of auxilios despite the 1991 prohibition suggests the need to establish rules for the allocation of the national budget in a clear and transparent fashion.

\section{The Use of Emergency Powers and the PMPs}

The enactment of economic legislation, particularly taxes, through the use of emergency powers has traditionally been a highly debated and scrutinized process, but also a particular characteristic of the Colombian PMPs. The use of special legislative powers by the executive has a long history. Starting in 1905 after the Thousand Days War, and continuing until 2002 when the state of internal commotion was declared in order to introduce a wealth tax earmarked for defense and security, very few presidents have refrained from using -or at least trying to use- these special powers.

Prior to 1991, the most commonly used exceptional state was the Estado de Sitio, which could be invoked with national or regional implications depending on the severity of the challenge to the public order. According to the data collected in Gallón (1978) and Cepeda (1985), presidents used this measure freely, especially during the Frente Nacional. In fact, in their respective four-year terms, President Lleras Camargo (1958-1962) spent 3.4 years under regional or national Estado de Sitio, Valencia (1962-1966) 1.2 years, Lleras Restrepo (1966-1970) 3.2 years, and Pastrana Borrero (1970-1974) 3.1 years.

The 1968 constitutional reform prohibited the use of the Estado de Sitio to legislate on economic matters such as taxes and introduced the Emergencia Económica y Social to deal with severe economic 
shocks. During the Estado de Sitio the President could change the budget with the consent of the cabinet. The 1991 Constitution eliminated this special state and introduced the more restricted Estado de Conmoción Interior, which was used for 180 days during the Gaviria (1990-2004) and Uribe administrations (2002-present), and for 90 days during Samper's presidency (1994-1998).

However, from an economic point of view, the most relevant special states are those related to economic and social emergencies. Measured as a proportion of the total number of the main economic laws enacted since 1982 (eight of a total of 189), or as a percentage of tax reforms (five out of 43), the economic legislation passed with emergency powers appears extremely low. The significance of emergency legislation, therefore, lies in the very special conditions required for its application. The 1886 Constitution restricted the enactment of legislation through executive powers to periods of war or internal commotion. The Constitutional Reform Act of 1910, adopted after the Reyes dictatorship, explicitly established that no new taxes could be introduced with the exercise of special faculties except at times of war. This precept was not strictly followed during the Depression, however, when the government was obliged to adopt economic legislation, including taxes, with exceptional regimes. A new constitutional interpretation introducing the concept of the rupture of public economic order was introduced in the mid-1940s and formalized several years later. The 1968 constitutional reform introduced Article 122, which allowed for the possibility to adopt exceptional powers as a result of the rupture of economic and social order. This article was used to pass a profound and radical tax reform under the López Administration in 1974. However, the Supreme Court rejected in 1982 the adoption of new taxes through an economic emergency during the Betancur Administration.
The 1991 Constitution restricted even further the possibility of imposing new taxes through the use of economic emergency provisions. New taxes could only be transitory during the period of the emergency, and the resources used strictly for purposes of resolving the causes of the emergency. An attempt to use economic emergency powers in 1997 by the Samper Administration was declared unconstitutional. Nonetheless, two economic emergencies (during the Pastrana Administration) and one internal commotion (during the Uribe Administration) led to the introduction of new taxes, with the approval of the Constitutional Court. Interestingly, in the three episodes the taxes introduced were temporary -according to the precepts of the constitution- but were later extended by legislation in normal times.

\section{E. Recapitulating the Key Implications of the 1991 Constitution for the PMPs}

The starting point is that a number of important policy issues were directly included in the constitution so that they essentially became off limits in terms of the regular legislation. The PMP in these areas now takes the form of constitutional amendments, which by definition are more difficult to pass than regular legislation. ${ }^{49}$ In addition, constitutional amendments, as well as regular lawmaking, have to face a more contested, fragmented and polarized Congress. As we will document below, this has implied a lower probability of bills' approval in Congress, particularly

\footnotetext{
49 Article 375 of the constitution restricts the initiation of constitutional amendments to the executive, 10 members of Congress, 20 percent of city councils and departmental legislators, or 5 percent of the electorate. The amendments have to be discussed in two ordinary and consecutive legislative periods, approved in the first round by the majority of the legislators present, while the second round has to be approved by the majority of the members of Congress. In the second round the debate is limited to initiatives discussed in the first round. In contrast, regular laws require only one round and a simple majority of the legislators present in the debate.
} 
for bills initiated by the executive. Pre-1991, it was easier for the executive to put together a winning coalition because the President had greater partisan powers, and the legislature was less fragmented. Also, the loss of the president's power to appoint governors, the shift in the financing of campaigns (from party-based to candidate-based), and the use of a ballot system that lowered the value of the party, had a negative impact on party discipline and may have also made it more difficult for the President to enact his agenda. In addition, once the President is able to get laws passed through Congress, constitutional review by the cc can derail or modify what comes out of the legislative.

As before, presidents have been able to bypass legislative debate by invoking exceptional circumstances (estados de excepción). However, prior to 1991 emergencies were easier to declare. Post-1991, there are stricter checks on whether emergencies were declared appropriately (by the cc), and limits (in terms of the duration of the emergency and the type of legislative decrees that can be adopted). More relevantly, prior to 1991 decrees issued during the emergency became laws automatically, whereas now they have to go through the normal legislative approval process for them to remain in effect after the emergency expires.

Finally, the president's reactive powers in order to block legislation also changed. The president's veto power was weakened by the 1991 Constitution. Pre1991 the president's veto was hard to override, as a two-thirds majority was required. Since 1991 only a simple majority is required to override a veto.

\section{EMPIRICAL EVIDENCE}

This section provides some empirical content to the previous discussion by using a legislative output database covering the period between 1982/1983 and
2002/2003. ${ }^{50}$ Legislative output is the information about the bills that have been presented and enacted in a given legislature. The database consists of 3,428 bills presented in the House of Representatives, and comes -since 1992- from its annual Informe Legislativo. Prior to 1992, the information was collected from the archive at the Library of Congress. ${ }^{51}$ For each bill initiated, the database contains the following information:

1. Number of the bill.

2. Title of bill.

3. Instance of entry into Congress (i.e., House or Senate).

4. Type of author (i.e., executive, legislative, other).

5. Party of the author.

6. Name and number of legislator(s) presenting it to the floor (we will use the term sponsor).

7. Party of the sponsor(s).

8. Committee where it was introduced (including the possibility of joint committees).

9. Number of debates at the end of the legislative year.

10. Status at the end of the legislative year (i.e., filed, incorporated into another bill, ${ }^{52}$ in process, or enacted).

\footnotetext{
50 See Mejía Acosta (1998), Amorim Neto (1998), Amorim Neto and Borsani (2004), and Morgenstern and Nacif (2000) for similar data and analyses for other Latin American countries.

51 The database is organized by legislative years, which begin on July 20 and end on June 20 of the following calendar year, with a scheduled recess from December 16 to March 16). The years 1986 and 1987 were not complete in the archive. For these two years we have complete information only for the bills introduced in the first 6 months of the legislative year.

52 This occurs when several initiatives dealing with similar issues are combined into one.
} 
We focus on the variables that explain why bills become laws and compare the executive and legislative capacity of enacting policy before and after 1991. Specifically, we want to test whether the agenda setting power of the executive means greater success rates for bill initiated by the government, and whether this has changed after 1991. As shown in Table 6, on average 179 laws were initiated annuaIly, prior to the enactment of the 1991 Constitution. Since then, congressional activity has intensified: 271 laws have been initiated per year. Bills initiated by the executive represent around 19 percent of the total, regardless of the time period. It is important to mention that we use data from the House only. Nevertheless, we can follow the path of bills that go through the Senate which have been introduced in the House. Also, our unit of analysis is the bill ins- tead of the legislator (as in the case of the databases constructed with roll-call data), so measuring party unity or party cohesion within Congress is not possible with these data.

To gain insight into the database, we borrowed the Taylor, Robinson and Díaz (1999) detailed typology to classify bills according to their scope: individual, local, regional, sectoral, national, and international treaties. This allows us to differentiate bills such as the "celebración de los 462 años de la fundación del municipio de Charalá" (PL.091/2002C) from bills that have a national or a sector-specific impact, such as those regulating professional activities. Bills that have a local or regional target are classified as "local scope" in our database, while sectoral or national bills are classified as "national scope". However, it

Table 6. BILL INITIATION BY AUTHOR ${ }^{a}$

\begin{tabular}{|c|c|c|c|c|c|c|c|}
\hline \multirow[b]{2}{*}{ Legislative Year } & \multicolumn{3}{|c|}{ Author } & \multirow[b]{2}{*}{$\begin{array}{l}\text { Total } \\
\text { Bills }\end{array}$} & \multicolumn{3}{|c|}{ Author } \\
\hline & $\begin{array}{l}\text { Legislator } \\
\text { Bills }\end{array}$ & $\begin{array}{c}\text { Government } \\
\text { Bills }\end{array}$ & $\begin{array}{l}\text { Other } \\
\text { Bills }\end{array}$ & & $\begin{array}{l}\text { Legislator } \\
(\%)\end{array}$ & $\begin{array}{c}\text { Government } \\
(\%)\end{array}$ & $\begin{array}{c}\text { Other } \\
(\%)\end{array}$ \\
\hline 1982-1983 & 99 & 39 & 2 & 140 & 70.7 & 27.9 & 1.4 \\
\hline 1983-1984 & 151 & 47 & 1 & 199 & 75.9 & 23.6 & 0.5 \\
\hline 1986-1987 & 115 & 19 & 3 & 137 & 83.9 & 13.9 & 2.2 \\
\hline 1987-1988 & 202 & 32 & 4 & 238 & 84.9 & 13.4 & 1.7 \\
\hline 1992-1993 & 270 & 67 & 13 & 350 & 77.1 & 19.1 & 3.7 \\
\hline 1994-1995 & 211 & 49 & 4 & 264 & 79.9 & 18.6 & 1.5 \\
\hline 1995-1996 & 271 & 58 & 2 & 331 & 81.9 & 17.5 & 0.6 \\
\hline 1996-1997 & 273 & 59 & 8 & 340 & 80.3 & 17.4 & 2.4 \\
\hline 1997-1998 & 166 & 64 & 8 & 238 & 69.7 & 26.9 & 3.4 \\
\hline 1998-1999 & 202 & 46 & 10 & 258 & 78.3 & 17.8 & 3.9 \\
\hline $1999-2000$ & 250 & 48 & 12 & 310 & 80.6 & 15.5 & 3.9 \\
\hline 2000-2001 & 188 & 37 & 7 & 232 & 81.0 & 15.9 & 3.0 \\
\hline 2001-2002 & 99 & 17 & - & 116 & 85.3 & 14.7 & - \\
\hline $2002-2003$ & 221 & 49 & - & 270 & 81.9 & 18.1 & - \\
\hline Total & 2,718 & 631 & 74 & $3,423^{b}$ & 79.4 & 18.4 & 2.2 \\
\hline Average pre-91 & 142 & 34 & 3 & 179 & 79.4 & 19.2 & 1.4 \\
\hline Average post-91 & 215 & 49 & 6 & 271 & 79.4 & 18.2 & 2.4 \\
\hline
\end{tabular}


is important to mention that these classifications are based on the limited information contained in the title of the bill, so care should be exercised when interpreting the results. ${ }^{53}$

Table 7 shows the distribution of bills by scope. As expected, the executive generally submits bills with a national scope, while Congress submits all types of bills. ${ }^{54}$ To compare the government and legislative success in enacting bills, we constructed a simple success ratio (enacted bills over bills introduced). This measure is imprecise because some bills are still being processed at the end of the legislative year, and have some probability of getting enacted in the following legislation. However, we do not know which laws in process during year $t$ are effectively enacted in year $t+1 .{ }^{55}$ Bills initiated by the executive systematically have higher success ratios for any type of scope. Bills initiated by legislators have relatively low chances of approval, especially in the case of

\section{Table 7. BILL INITIATION BY POLICY SCOPE}

\begin{tabular}{|c|c|c|c|c|c|c|c|c|c|}
\hline & \multicolumn{6}{|c|}{ Initiative } & & & \\
\hline & \multicolumn{3}{|c|}{ Congress } & \multicolumn{3}{|c|}{ Executive } & \multicolumn{3}{|c|}{ Total } \\
\hline & $\begin{array}{c}\text { Before } \\
1991\end{array}$ & $\begin{array}{l}\text { After } \\
1991\end{array}$ & $\begin{array}{c}\text { All } \\
\text { periods }\end{array}$ & $\begin{array}{c}\text { Before } \\
1991\end{array}$ & $\begin{array}{l}\text { After } \\
1991\end{array}$ & $\begin{array}{c}\text { All } \\
\text { periods }\end{array}$ & $\begin{array}{c}\text { Before } \\
1991\end{array}$ & $\begin{array}{l}\text { After } \\
1991\end{array}$ & $\begin{array}{c}\text { All } \\
\text { periods }\end{array}$ \\
\hline \multicolumn{10}{|c|}{ Scope of the Bill } \\
\hline Individual & 41 & 53 & 94 & 5 & 1 & 6 & 46 & 54 & 100 \\
\hline Local & 71 & 137 & 208 & 7 & 2 & 9 & 78 & 139 & 217 \\
\hline Sectoral & 23 & 166 & 189 & 3 & 8 & 11 & 26 & 174 & 200 \\
\hline Regional & 69 & 100 & 169 & 4 & 2 & 6 & 73 & 102 & 175 \\
\hline National & 329 & 929 & 1,258 & 73 & 195 & 268 & 402 & 1,124 & 1,526 \\
\hline Int. Treaties & - & 2 & 2 & 40 & 122 & 162 & 40 & 124 & 164 \\
\hline Total & 533 & 1,387 & 1,920 & 132 & 330 & 462 & 665 & 1,717 & $2,382^{a}$ \\
\hline \multicolumn{10}{|c|}{ Success ratios $(\%)$} \\
\hline Individual & 41.46 & 41.51 & 41.49 & 40 & 100 & 50 & 41.30 & 42.59 & 42 \\
\hline Local & 8.45 & 3.65 & 5.29 & 71.43 & 50 & 66.67 & 14.10 & 4.32 & 7.83 \\
\hline Sectoral & 26.09 & 16.27 & 17.46 & 33.33 & 75 & 63.64 & 26.92 & 18.97 & 20.00 \\
\hline Regional & 39.13 & 17.00 & 26.04 & 100 & 100 & 100 & 42.47 & 18.63 & 28.57 \\
\hline National & 12.46 & 13.02 & 12.88 & 65.75 & 67.18 & 66.79 & 22.14 & 22.42 & 22.35 \\
\hline Int. Treaties & - & - & - & 70 & 91.80 & 86.42 & 70.00 & 90.32 & 85.37 \\
\hline Total & 18.20 & 13.84 & 15.05 & 66.67 & 76.67 & 73.81 & 27.82 & 25.92 & $26.45^{b}$ \\
\hline
\end{tabular}

a Laws introduced between 20/07/82 and 27/06/03. Excludes 79 bills presented by other instances and bills in process. Source: Authors' calculations based on Informes Legislativos del Congreso, several issues.

\footnotetext{
53 Even within bills with a national scope there is great diversity. Take, for example, the case of bill 183/2003C that seeks to establish the national day for forgiveness and reconciliation.

54 Within the government, the ministers of Foreign Affairs and Finance are the leaders in terms of bill initiatives.

55 Thus, we underestimate success ratios, compared to what could appear by looking at an entire four-year Presidential or congressional term.
} 
laws with a local and national scope. ${ }^{56}$ Also, regardless of policy scope and initiation, success rates have fallen after 1991.

We also used a classification of bills according to their policy area. In particular, based on the bill's title we classify them in the following areas: ${ }^{57}$

1. Taxation

2. Budget

3. Foreign Trade

4. Financial markets

5. Monetary and exchange rate policies

6. Pensions

7. Other economic policies (e.g. agrarian reform)

8. Non-economic.

Table 8 presents the results, where we aggregate categories 3, 4, and 5 as well as categories 6 and 7 . As shown, budgetary bills have the highest success rate. In all cases, again, success rates drastically fell after 1991.

\section{A. Econometric Tests and Results}

This section presents the results of a logit regression that uses as dependent variable the probability of a bill being enacted. As mentioned above, at the end of the legislative year a bill can be enacted (our definition of "success" regardless of the impact of the law), filed (which means that the initiative was defeated), or allowed to remain in process for consideration in

\footnotetext{
56 Saeigh (2003) calculates annual success rates for different regimes. When compared with that evidence, the Colombian executive has a lower success rate (40.6 percent) than other presidential systems, including Argentina (62 percent). In this context, Colombia looks more like Chile or Ecuador (1979-1996).

57 However, when a bill deals with various topics, we make a judgment call on what constitutes its most salient topic.
}

the next legislative year. To avoid estimation biases we excluded bills that are still in process, mainly because it would be imprecise to treat them as cases of failure or success, as explained above. The model includes all legislative years in the database, with the exception of bills dealing with the ratification of international treaties, where Congress essentially rubberstamps negotiations conducted by the executive. ${ }^{58}$ It is important to note that the success ratio assumes every bill to be of same importance. For example, a tax reform is weighted the same as an honorific bill enacted by the legislature.

The purpose of the econometric exercise is twofold. First, we want to identify the factors that determine success rates in legislative activity in general. Second, we want to disentangle the effects of the 1991 Constitution. In particular, we explore the role of greater polarization and fragmentation -as well as diminished presidential powers- discussed in the previous section. In all cases, the dependent variable takes a value equal to one in the case of initiatives that become laws, and zero otherwise. The explanatory variables include a dummy that takes a value of one when bills are initiated after 1991 and zero otherwise (Post 1991), a dummy that takes a value of one when bills are initiated by the executive (Executive), a dummy with a value of one when the bill is initiated during the last year of the administration (Last Year), a dummy for bills that have a national scope ( $\mathrm{Na}$ tional), a dummy for bills that are discussed in the constitutional committee (Constitutional), a dummy for bills that are discussed in the economic committee (Economic), and a variable that measures each bill's number of sponsors (Sponsors). In addition, we also used two variables that capture the polarization and fragmentation of the political system. This is the case

\footnotetext{
58 After excluding these bills, the number of observations in the sample falls from 3,428 to 2,278 .
} 
Table 8. SUCCESS RATIO OF ECONOMIC BILLS BY THEME

\begin{tabular}{|c|c|c|c|c|c|c|c|c|c|c|c|c|}
\hline \multirow[b]{2}{*}{ Year } & \multicolumn{4}{|c|}{ Tax } & \multicolumn{4}{|c|}{ Budgetary } & \multicolumn{4}{|c|}{ Trade Finance and Exchange Rate } \\
\hline & $\begin{array}{c}\text { Presented } \\
\text { (bills) }\end{array}$ & $\begin{array}{c}\text { Enacted } \\
\text { (bills) }\end{array}$ & $\begin{array}{l}\text { In process } \\
\text { (bills) }\end{array}$ & $\begin{array}{c}\text { Success } \\
\text { Ratio (\%) }\end{array}$ & $\begin{array}{c}\text { Presented } \\
\text { (bills) }\end{array}$ & $\begin{array}{c}\text { Enacted } \\
\text { (bills) }\end{array}$ & $\begin{array}{l}\text { In process } \\
\text { (bills) }\end{array}$ & $\begin{array}{c}\text { Success } \\
\text { Ratio (\%) }\end{array}$ & $\begin{array}{c}\text { Presented } \\
\text { (bills) }\end{array}$ & $\begin{array}{c}\text { Enacted } \\
\text { (bills) }\end{array}$ & $\begin{array}{l}\text { In process } \\
\text { (bills) }\end{array}$ & $\begin{array}{c}\text { Success } \\
\text { Ratio (\%) }\end{array}$ \\
\hline 1982 & 5 & 1 & - & 20 & 17 & 9 & - & 53 & 8 & 3 & - & 38 \\
\hline 1983 & 24 & 12 & 1 & 52 & 19 & 13 & - & 68 & 8 & 3 & - & 38 \\
\hline 1984 & - & - & - & - & - & - & - & - & - & - & - & - \\
\hline 1985 & - & - & - & - & - & - & - & - & - & - & - & - \\
\hline 1986 & 6 & 1 & - & 17 & 11 & 4 & 1 & 40 & 2 & 1 & - & 50 \\
\hline 1987 & 6 & - & - & - & 27 & 12 & 2 & 48 & 1 & - & - & - \\
\hline 1992 & 6 & 1 & - & 17 & 7 & 5 & - & 71 & 7 & 5 & 1 & 83 \\
\hline 1993 & 6 & 1 & - & 17 & 1 & - & - & - & 2 & 2 & - & 100 \\
\hline 1994 & 5 & 0 & 4 & - & 5 & 2 & 1 & 50 & 4 & 2 & 2 & 100 \\
\hline 1995 & 15 & 4 & 8 & 57 & 11 & 4 & 5 & 67 & 6 & - & 4 & - \\
\hline 1996 & 20 & 2 & 11 & 22 & 10 & 6 & - & 60 & 7 & 1 & 4 & 33 \\
\hline 1997 & 15 & - & 12 & - & 4 & 1 & 3 & 100 & 10 & 1 & 8 & 50 \\
\hline 1998 & 20 & 2 & 11 & 22 & 7 & 3 & 3 & 75 & 8 & 4 & 1 & 57 \\
\hline 1999 & 27 & 11 & 5 & 50 & 10 & 6 & - & 60 & 4 & 3 & - & 75 \\
\hline 2000 & 29 & 5 & 8 & 24 & 10 & 5 & - & 50 & 3 & 1 & - & 33 \\
\hline 2001 & 20 & - & 15 & - & 8 & 3 & 4 & 75 & 6 & 1 & 3 & 33 \\
\hline 2002 & 13 & 2 & 2 & 18 & 13 & 4 & 5 & 50 & 2 & - & 1 & - \\
\hline 2003 & 6 & 1 & 1 & 20 & 1 & - & - & - & 2 & - & 1 & - \\
\hline Bef. 91 & 41 & 14 & 1 & 35 & 74 & 38 & 3 & 54 & 19 & 7 & - & 37 \\
\hline Aft. 91 & 182 & 29 & 77 & 28 & 87 & 39 & 21 & 59 & 61 & 20 & 25 & 56 \\
\hline \multirow[t]{2}{*}{ Total } & 223 & 43 & 78 & 30 & 161 & 77 & 24 & 56 & 80 & 27 & 25 & 49 \\
\hline & \multicolumn{4}{|c|}{ Other Economic } & \multicolumn{4}{|c|}{ Non Economic } & \multicolumn{4}{|c|}{ Total } \\
\hline Year & $\begin{array}{c}\text { Presented } \\
\text { (bills) }\end{array}$ & $\begin{array}{c}\text { Enacted } \\
\text { (bills) }\end{array}$ & $\begin{array}{l}\text { In process } \\
\text { (bills) }\end{array}$ & $\begin{array}{l}\text { Success } \\
\text { Ratio (\%) }\end{array}$ & $\begin{array}{c}\text { Presented } \\
\text { (bills) }\end{array}$ & $\begin{array}{c}\text { Enacted } \\
\text { (bills) }\end{array}$ & $\begin{array}{l}\text { In process } \\
\text { (bills) }\end{array}$ & $\begin{array}{c}\text { Success } \\
\text { Ratio (\%) }\end{array}$ & $\begin{array}{c}\text { Presented } \\
\text { (bills) }\end{array}$ & $\begin{array}{c}\text { Enacted } \\
\text { (bills) }\end{array}$ & $\begin{array}{l}\text { In process } \\
\text { (bills) }\end{array}$ & $\begin{array}{c}\text { Success } \\
\text { Ratio (\%) }\end{array}$ \\
\hline 1982 & 2 & - & 18 & 99 & 45 & 1 & 46 & 140 & 60 & 1 & 43 & - \\
\hline 1983 & 28 & 8 & - & 29 & 120 & 58 & 5 & 50 & 199 & 94 & 6 & 49 \\
\hline 1984 & - & - & - & - & - & - & - & - & - & - & - & - \\
\hline 1985 & - & - & - & - & - & - & - & - & - & - & - & - \\
\hline 1986 & 22 & 3 & - & 14 & 96 & 10 & 11 & 12 & 137 & 19 & 12 & 15 \\
\hline 1987 & 33 & 13 & 1 & 41 & 171 & 32 & 15 & 21 & 238 & 57 & 18 & 26 \\
\hline 1992 & 9 & 2 & - & 22 & 161 & 45 & 5 & 29 & 190 & 58 & 6 & 32 \\
\hline 1993 & 7 & 1 & - & 14 & 130 & 34 & 4 & 27 & 146 & 38 & 4 & 27 \\
\hline 1994 & 9 & - & 7 & - & 141 & 9 & 100 & 22 & 164 & 13 & 114 & 26 \\
\hline 1995 & 8 & 1 & - & 13 & 316 & 55 & 142 & 32 & 356 & 64 & 159 & 32 \\
\hline 1996 & 2 & - & - & - & 283 & 46 & 94 & 24 & 322 & 55 & 109 & 26 \\
\hline 1997 & 4 & 1 & 2 & 50 & 255 & 19 & 123 & 14 & 288 & 22 & 148 & 16 \\
\hline 1998 & 5 & 1 & 2 & 33 & 174 & 24 & 50 & 19 & 214 & 34 & 67 & 23 \\
\hline 1999 & 10 & 5 & 1 & 56 & 257 & 75 & 36 & 34 & 308 & 100 & 42 & 38 \\
\hline 2000 & 6 & 1 & - & 17 & 170 & 28 & 48 & 23 & 218 & 40 & 56 & 25 \\
\hline 2001 & 9 & 1 & 4 & 20 & 176 & 6 & 128 & 13 & 219 & 11 & 154 & 17 \\
\hline 2002 & 10 & 2 & 2 & 25 & 124 & 12 & 36 & 14 & 162 & 20 & 46 & 17 \\
\hline 2003 & 5 & 1 & - & 20 & 113 & 26 & 36 & 34 & 127 & 28 & 38 & 31 \\
\hline Bef. 91 & 94 & 26 & 1 & 28 & 486 & 145 & 32 & 32 & 714 & 230 & 37 & 34 \\
\hline Aft. 91 & 84 & 16 & 18 & 24 & 2,300 & 379 & 802 & 25 & 2,714 & 483 & 943 & 27 \\
\hline Total & 178 & 42 & 19 & 26 & 2,786 & 524 & 834 & 27 & 3,428 & 713 & 980 & 29 \\
\hline
\end{tabular}

Source: Authors' calculations based on Informes Legislativos del Congreso, several issues. 
of the effective number of political parties (Parties) and the number of lists competing in the previous election (Lists).

Table 9 presents the results. Equation 1, which tests our basic hypotheses, shows that success rates have fallen significantly after 1991, while bill initiatives originated by the executive have a higher probability of success, relative to those initiated by Congress. Interestingly, the interaction of these two variables has a positive and significant coefficient, suggesting that after 1991 the executive has been more effective in enacting laws than before, contrary to our analysis of the PMPs during that period. The other variables in the equation show that bills introduced during the last year of the administration and bills that have a national scope are less likely to pass, suggesting the presence of a "lame duck" effect and a bias in favor of laws that have a local or regional scope. Interestingly, bills that begin legislative discussion in the constitutional committee have a lower probability of success. This is important because, as mentioned

Table 9. DETERMINANTS OF LEGISLATIVE SUCCESS RATES (1982-2003)

\section{Logit Model}

Dependent variable (=0 if bill filed, 1 if enacted)

\begin{tabular}{|c|c|c|c|c|}
\hline $\begin{array}{l}\text { Equation No. } \\
\text { Sample }\end{array}$ & $\begin{array}{l}\text { (1) } \\
\text { All }\end{array}$ & $\begin{array}{l}(2) \\
\text { All }\end{array}$ & $\begin{array}{l}(3) \\
\text { All }\end{array}$ & $\begin{array}{l}(4) \\
\text { All }\end{array}$ \\
\hline Constant & $\begin{array}{l}-0.427^{* * *} \\
(0.123)\end{array}$ & $\begin{array}{l}-0.419 * * * \\
(0.131)\end{array}$ & $\begin{array}{l}1.459 * * * \\
(0.390)\end{array}$ & $\begin{array}{r}0.328 \\
(0.246)\end{array}$ \\
\hline Post-1991 & $\begin{array}{l}-0.550 * * \\
(0.125)\end{array}$ & $\begin{array}{l}-0.636^{* * *} \\
(0.137)\end{array}$ & $\begin{array}{l}-0.295^{* *} \\
(0.150)\end{array}$ & $\begin{array}{r}0.063 \\
(0.233)\end{array}$ \\
\hline Executive's initiative & $\begin{array}{l}2.059 \text { *** } \\
(0.258)\end{array}$ & $\begin{array}{l}2.020^{* * *} \\
(0.274)\end{array}$ & $\begin{array}{l}2.011^{* * *} \\
(0.275)\end{array}$ & $\begin{array}{l}2.032^{* * *} \\
(0.275)\end{array}$ \\
\hline Post-1991 * Executive's initiative & $\begin{array}{l}0.642 * * \\
(0.305)\end{array}$ & $\begin{array}{r}0.388 \\
(0.334)\end{array}$ & $\begin{array}{r}0.532 \\
(0.337)\end{array}$ & $\begin{array}{r}0.344 \\
(0.335)\end{array}$ \\
\hline Last year in office & $\begin{array}{l}-0.792 * * \\
(0.253)\end{array}$ & $\begin{array}{l}-1.026^{* * *} \\
(0.279)\end{array}$ & $\begin{array}{l}-1.087^{* * *} \\
(0.282)\end{array}$ & $\begin{array}{l}-1.020^{* * *} \\
(0.280)\end{array}$ \\
\hline National scope & $\begin{array}{l}-0.593 * * * \\
(0.119)\end{array}$ & $\begin{array}{l}-0.704^{* * *} \\
(0.129)\end{array}$ & $\begin{array}{l}-0.752 * * * \\
(0.130)\end{array}$ & $\begin{array}{l}-0.734^{* * *} \\
(0.129)\end{array}$ \\
\hline Constitutional committee & $\begin{array}{l}-0.891^{* * *} \\
(0.136)\end{array}$ & $\begin{array}{l}-0.772 * * * \\
(0.148)\end{array}$ & $\begin{array}{l}-0.743 * * * \\
(0.149)\end{array}$ & $\begin{array}{l}-0.794^{* * *} \\
(0.148)\end{array}$ \\
\hline Economic committee & $\begin{array}{l}-0.150 \\
(0.154)\end{array}$ & $\begin{array}{l}-0.237 \\
(0.166)\end{array}$ & $\begin{array}{l}-0.253 \\
(0.167)\end{array}$ & $\begin{array}{l}-0.218 \\
(0.167)\end{array}$ \\
\hline Number of sponsors & - & $\begin{array}{l}0.205^{* * *} \\
(0.044)\end{array}$ & $\begin{array}{l}0.176 * * * \\
(0.043)\end{array}$ & $\begin{array}{l}0.231^{* * *} \\
(0.045)\end{array}$ \\
\hline Effective number of parties & $\begin{array}{l}- \\
-\end{array}$ & - & $\begin{array}{l}-0.820 \text { *** } \\
(0.161)\end{array}$ & $\begin{array}{l}- \\
-\end{array}$ \\
\hline Number of lists (x100) & - & - & - & $\begin{array}{l}-0.225^{* * *} \\
(0.063)\end{array}$ \\
\hline Number of obs. & 2,278 & 1,789 & 1,789 & 1,789 \\
\hline LR $\mathrm{chi}^{2}$ & 415.74 & 365.88 & 395.14 & 379.27 \\
\hline Pseudo $\mathrm{R}^{2}$ & 0.16 & 0.16 & 0.18 & 0.17 \\
\hline Log likelihood & $-1,076.96$ & -913.51 & -898.89 & -906.818 \\
\hline
\end{tabular}

*** Significant at $1 \%,{ }^{* *}$ significant at $5 \%$, significant at $10 \%$. Source: Authors' calculations. 
above, much of the PMP after 1991 requires constitutional amendments (due to the level of detail and specificity of the constitution), which by definition initiate the legislative discussion in the constitutional committees. Therefore, constitutional amendments are harder to pass than regular legislation. Bills that enter Congress through the economic committees do not seem to be any different than the rest.

We have shown in Figure 8 that the number of sponsors assigned to each law has increased since 1991. As discussed above, the number of sponsors is a good proxy for the amount of pork that the executive has to deliver in order to pass a law. The hypothesis is that the greater the number of sponsors, the larger the amount of pork that the administration is willing to provide and the higher the chances of approval by the floor. This is precisely what we obtain in equation 2 when we add the number of sponsors as an explanatory variable. Importantly, the interacted term between the dummy post 1991 and the executive variable loses all significance, suggesting that the more apparent success of the executive is the result of greater use of sponsors (i.e., pork) since 1991 to assist the legislative process. Equations 3 and 4 add the effective number of parties and the number of lists, respectively. As expected, both variables have a negative impact on the bill's chances of success, implying that greater fragmentation and polarization make the legislative process more difficult. All other variables remain significant, except in equation 4 for the Post 1991 dummy. This is interesting because it suggests that the decrease in the probability of success after 1991 is effectively explained by the increase in the number of lists (a measure of fragmentation) that has taken place since the enactment of the new constitution.

Transforming the estimated coefficients of equations 3 and 4 into marginal effects on the probability is a straightforward exercise, which is shown in Table 10. According to equation 3 (which has the highest $\mathrm{R}$ squared), the estimated probability is 26.8 percent, which is marginally altered by changes in the explanatory variables. For instance, when the bill is initiated by the executive, the probability increases by 45.6 percent; in contrast, when the bill is introduced during the administration's last year the probability falls by 16.6 percent, if it has a national scope the probability falls by 15.5 percent, and if it is introduced through the constitutional committee the probability diminishes by 13.6 percent. At the same time, an extra sponsor raises the probability by 3.4 percent, while an extra political party lowers it by 16.1 percent. Figure 10 shows the partial effects on the probabilities of success of the relevant expla-

\section{Table 10. MARGINAL EFFECTS ONTHE PROBABI-} LITIES BASED ON THE LOGIT REGRESSION

\begin{tabular}{|c|c|c|}
\hline Variable & Equation 3 & Equation 4 \\
\hline Post-1991 a & $\begin{array}{l}-0.059 * \\
(0.031)\end{array}$ & $\begin{array}{r}0.012 \\
(0.046)\end{array}$ \\
\hline Executive's initiative $^{a}$ & $\begin{array}{l}0.456 * * * \\
(0.059)\end{array}$ & $\begin{array}{l}0.462 \text { *** } \\
(0.058)\end{array}$ \\
\hline Post-1991 X Executive's initiative ${ }^{a}$ & $\begin{array}{r}0.114 \\
(0.077)\end{array}$ & $\begin{array}{r}0.072 \\
(0.074)\end{array}$ \\
\hline Last year in office ${ }^{a}$ & $\begin{array}{l}-0.166^{* * *}{ }_{-} \\
(0.031)\end{array}$ & $\begin{array}{l}0.160 \text { *** } \\
(0.033)\end{array}$ \\
\hline National Scope ${ }^{a}$ & $\begin{array}{l}-0.155^{* * *} \\
(0.028)\end{array}$ & $\begin{array}{l}-0.153^{* * *} \\
(0.028)\end{array}$ \\
\hline Constitutional committee $^{\mathrm{a}}$ & $\begin{array}{l}-0.136^{* * *} \\
(0.025)\end{array}$ & $\begin{array}{l}-0.146^{* * *} \\
(0.025)\end{array}$ \\
\hline Economic committee $^{a}$ & $\begin{array}{l}-0.048 \\
(0.030)\end{array}$ & $\begin{array}{l}-0.042 \\
(0.031)\end{array}$ \\
\hline Number of sponsors & $\begin{array}{l}0.034^{* * *} \\
(0.009\end{array}$ & $\begin{array}{l}0.046^{* * *} \\
(0.009)\end{array}$ \\
\hline Effective number of parties & $\begin{array}{l}-0.161^{* * *} \\
(0.031)\end{array}$ & $\begin{array}{l}- \\
-\end{array}$ \\
\hline Number of lists (X100) & $\begin{array}{l}- \\
-\end{array}$ & $\begin{array}{l}-0.045^{* * *} \\
(0.012)\end{array}$ \\
\hline Marginal effect after logit ${ }^{b}$ & 0.268 & 0.272 \\
\hline \multicolumn{3}{|c|}{$\begin{array}{l}{ }^{a} \mathrm{dy} / \mathrm{dx} \text { is for discrete change of dummy variable from } 0 \text { to } 1 \\
\text { b Estimated probability of the model for a bill to became law } \\
{[y=\operatorname{Pr} \text { (bill_law) (predict)]. }} \\
{ }^{* * *} \text { Significant at } 1 \%,{ }^{* *} \text { significant at } 5 \%{ }^{*} \text { significant at } 10 \%\end{array}$} \\
\hline
\end{tabular}


natory variables in the regressions, using as a benchmark bills initiated after 1991, during the first three years of the administration, through committees other than the constitutional committee and with a national scope. The charts show how the probabilities augment with the number of sponsors, and decrease with the number of parties and lists.

Finally, we performed a similar econometric exercise for different groups of bills sorted by policy area (Table 11). In the case of bills that deal with budgetary matters the executive variable is very strong, as well as the number of sponsors. The other variables are less significant in this case (see equations 5 and 6). In the case of bills that deal with all other economic matters the negative effect of bills that deal with national issues appears to be relevant (equations 6 and 7). For bills that deal with non-economic issues (equations 8 and 9), the results are very similar to the ones described above in the context of equations 1 to 4 .

In the remaining sections of this paper we describe the key policy characteristics or "outer features" of some policy areas. With the purpose of exploiting variation across time and across sectors, we focus on specific aspects of fiscal, monetary, and exchange rate policies. The idea is not to provide a detailed account of these policies or a complete taxonomy, but to identify those features and characteristics that can be related to the workings of the political institutions and the policymaking process. Given that lens, the implicit notion of optimal policy involves policies that are resilient to political shocks (or, more generally, to changes in the political landscape), but that are flexible enough to adjust to economic shocks. Finally, in the description we also highlight some specific aspects of those policy areas, other than political institutions, that are useful in understanding their outer features.

\section{Figure 10. PROBABILITY OF SUCCESS}

Probability of Succes Based on Equation 3

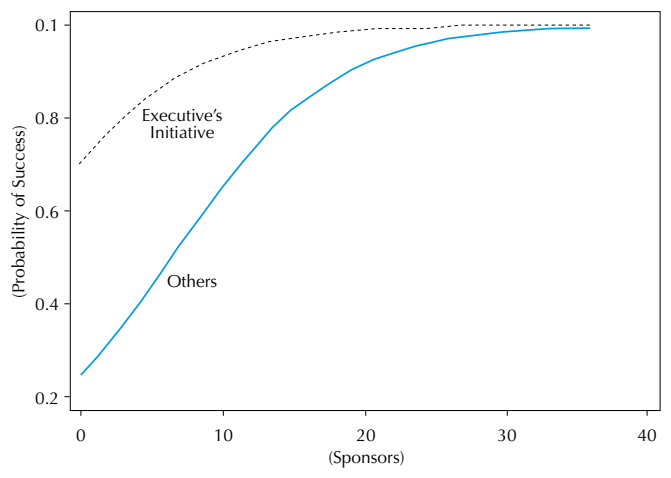

Probability of Succes Based on Equation 3

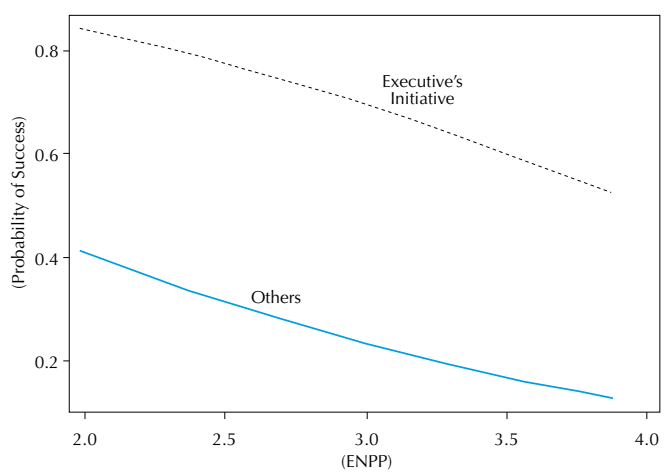

Probability of Succes Based on Equation 4

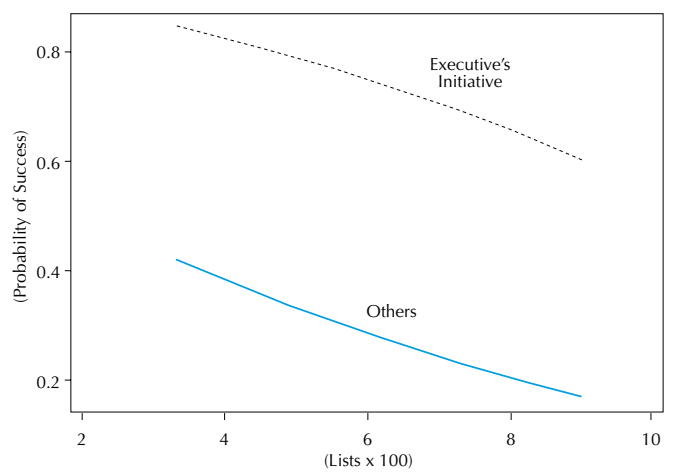

Bills initiated after 1991, during the first three years of the administration, through committees other than the constitutional or economic committiees and with a national scope. Source: Authors' calculations. 
Table 11. DETERMINANTS OF LEGISLATIVE SUCCESS RATES (1982-2003)

Logit Model

Dependent variable (=0 if bill filed, 1 if enacted)

\begin{tabular}{|c|c|c|c|c|c|c|}
\hline $\begin{array}{l}\text { Equation No. } \\
\text { Sample }\end{array}$ & $\begin{array}{c}\text { (5) } \\
\text { Budget }\end{array}$ & $\begin{array}{c}\text { (6) } \\
\text { Budget }\end{array}$ & $\begin{array}{c}(7) \\
\text { Other } \\
\text { economic }\end{array}$ & $\begin{array}{c}(8) \\
\text { Other } \\
\text { economic }\end{array}$ & $\begin{array}{c}(9) \\
\text { Non } \\
\text { economic }\end{array}$ & $\begin{array}{c}(10) \\
\text { Non } \\
\text { economic }\end{array}$ \\
\hline \multirow[t]{2}{*}{ Constant } & -0.166 & 2.026 & $-0.716^{* * *}$ & -0.061 & $-0.361^{* *}$ & 0.376 \\
\hline & $(0.437)$ & $(1.477)$ & $(0.275)$ & $(0.637)$ & $(0.148)$ & $(0.280)$ \\
\hline \multirow[t]{2}{*}{ Post-1991 } & -1.156 & 0.548 & -0.305 & 0.378 & $-0.644 * * *$ & -0.089 \\
\hline & $(0.749)$ & $(1.520)$ & $(0.302)$ & $(0.642)$ & $(0.146)$ & $(0.259)$ \\
\hline \multirow[t]{2}{*}{ Executive's initiative } & $2.288 * * *$ & $2.713^{* * *}$ & $1.681 * * *$ & $1.389 * *$ & $2.007^{* * *}$ & $1.967 * * *$ \\
\hline & $(0.681)$ & $(0.803)$ & $(0.615)$ & $(0.662)$ & $(0.355)$ & $(0.378)$ \\
\hline \multirow[t]{2}{*}{ Post-1991 * Executive's initiative } & $1.904^{*}$ & 1.511 & 1.004 & 0.895 & 0.516 & 0.327 \\
\hline & $(0.987)$ & $(1.250)$ & $(0.767)$ & $(0.842)$ & $(0.404)$ & $(0.436)$ \\
\hline \multirow[t]{2}{*}{ Last year in office } & -0.193 & -0.967 & -0.420 & -0.539 & $-0.998 * * *$ & $-1.137 * * *$ \\
\hline & $(0.836)$ & $(0.979)$ & $(0.837)$ & $(0.874)$ & $(0.307)$ & $(0.326)$ \\
\hline \multirow[t]{2}{*}{ National scope } & -0.855 & $-1.339 *$ & $-0.897^{* * *}$ & $-1.018^{* * *}$ & $-0.534 * * *$ & $-0.654 * * *$ \\
\hline & $(0.602)$ & $(0.704)$ & $(0.306)$ & $(0.334)$ & $(0.138$ & $(0.150)$ \\
\hline \multirow[t]{2}{*}{ Constitutional committee } & $-1.539 *$ & -1.564 & $-1.600 *$ & -1.007 & $-0.849 * * *$ & $-0.820 * * *$ \\
\hline & $(0.920)$ & $(0.982)$ & $(0.851)$ & $(0.872)$ & $(0.146)$ & $(0.160)$ \\
\hline \multirow[t]{2}{*}{ Economic committee } & 0.117 & 0.164 & 0.112 & 0.263 & -0.277 & -0.380 \\
\hline & $(0.568)$ & $(0.622)$ & $(0.288)$ & $(0.309)$ & $(0.263)$ & $(0.282)$ \\
\hline \multirow[t]{2}{*}{ Number of sponsors } & - & $0.384 *$ & - & $0.163 *$ & - & $0.232 * * *$ \\
\hline & - & $(0.228)$ & - & $(0.095)$ & - & $(0.056)$ \\
\hline \multirow[t]{2}{*}{ Number of lists (x 100) } & - & -0.679 & - & -0.230 & - & $-0.211 * * *$ \\
\hline & - & $(0.431)$ & - & $(0.179)$ & - & $(0.069)$ \\
\hline Number of obs & 137 & 124 & 330 & 276 & 1,811 & 1,389 \\
\hline LR chi ${ }^{2}$ & 61.88 & 68.64 & 44.67 & 41.87 & 260.98 & 237.07 \\
\hline Pseudo $\mathrm{R}^{2}$ & 0.32 & 0.41 & 0.11 & 0.12 & 0.13 & 0.14 \\
\hline Log likelihood & -62.96 & -48.89 & -171.03 & -149.48 & -833.24 & -697.48 \\
\hline
\end{tabular}

*** Significant at $1 \%,{ }^{* *}$ significant at $5 \%$, ${ }^{*}$ significant at $10 \%$.

Source: Authors' calculations.

\section{FISCAL POLICY}

To identify the outer features of fiscal policy we will divide the analysis in three parts. We start by discussing fiscal policies in relation to oil and coffee exports. Analytically, this is a rich area due to variation across sectors (e.g., the number of relevant actors is larger in oil than in coffee) and time (e.g., coffee being a critical source of fiscal and foreign exchange revenues until the 1980s and oil thereafter). Secondly, we discuss issues related to the national government, which handles most tax revenues and transfers an increasing share of those revenues to the regions. Thirdly, we look into pensions, which are the fastest growing public expenditure.

\section{A. Oil and Coffee}

Public finances in Colombia have been highly dependent on coffee and oil taxation. In particular, coffee policy was a key component of fiscal policies before the enactment of the 1991 Constitution, 
particularly during the Frente Nacional years. Oil policy has been a key element of public finances in the post-1991 years. ${ }^{59}$ The constitution was written during a time of major oil discoveries, explaining the generosity in terms of protection of social rights and lack of emphasis on aspects related to fiscal sustainability.

Here, we explore the policymaking processes whereby coffee and oil revenues are distributed among different groups in society. Also, as these export revenues are intrinsically volatile, it is critical to reach intertemporal agreements for the implementation of consistent fiscal policies (i.e., policies that prevent overconsumption during booms). The outer features of the policies that address these issues are very different in the case of oil (post-1991), compared to coffee in the previous years, reflecting differences in the underlying political institutions, but also diversity in the specific characteristics of these two policy areas.

As mentioned in Section 4, the rules of the political game during the Frente Nacional facilitated complex intertemporal exchanges in economic policy. No other sector illustrates better these exchanges than coffee policy. In 1958, the same year that the Frente Nacional was agreed upon, world coffee prices collapsed, sending producers into a deep crisis. That year, the National Coffee Fund (NCF) became the instrument for the stabilization of producers' incomes. By its very nature, stabilization implied savings during booms and dis-saving during busts. In either case, cooperation was a prerequisite. Bates (1997) argues that coffee producers in Colombia have been

59 To put this in context, oil exports have represented on average 30 percent of exports after 1991, while coffee represented on average 50 percent of exports between 1958 and 1986 (and only 15 percent since 1991). Due to the collapse in world prices, and the diversification of exports, coffee has lost most of its fiscal and foreign exchange relevance in recent times. traditionally at the center of the political spectrum. A candidate willing to win office requires the support of this group, which therefore has become pivotal in electoral turnouts. Consequently, Liberal and Conservative governments adopted similar policies in order to stabilize the effects of external shocks that were welfare reducing for the median voter. Technocrats and coffee producers shared similar objectives and mutually reinforced their respective powers. The Minister of Finance (and, obviously, the President) and the leadership of coffee producers were the only relevant players in negotiating the intertemporal trades that involved a substantial share of public finances.

According to the evidence presented in Cárdenas and Partow (1998), electoral and partisan cycles did not play a role in the redistribution of coffee export revenues to other groups. In this sense, the NCF was a flexible instrument that dealt with the amount of redistribution to other sectors and the degree of stabilization of domestic prices. Its decisions were the result of a two-player game (the executive and coffee producers represented by the Coffee Growers Federation), without the participation of other actors, such as Congress or the courts. As a result of that interaction, coffee policies were stable (i.e., intertemporal agreements were sustained) and flexible (i.e., adjusted rapidly to changes in international and domestic conditions).

In light of the potentially destabilizing effects of an oil boom, Congress approved in 1995 the creation of Oil Stabilization Fund (OSF). In contrast to coffee, redistribution is based on a rigid system of royalties allocated among the producing departments and municipalities (including those where ports are located) and the National Royalties Fund (NRF), which in turn redistributes to other departments and municipalities. Depending on the value of exports, the OSF 
forces saving by all recipients of oil rents and invests the proceeds abroad. The large number of players with power over a given decision (national and local governments, as well as Ecopetrol), the short-term nature of the interaction between the key actors (governors, majors and the executive), the high discount rate of these actors, and the difficulty in delegating policies to a third party, create an environment with high transactions costs. The natural consequence is that the cooperative solution that provides some stability (i.e., savings during high export years) is embodied in a rigid system of rules, costly to change, even if those changes are desirable.

\section{B. National Government}

Total expenditures by the central government have doubled from an average of 10 percent of GDP during the 1980s to an average of 20 percent since 1999. As a result of eight tax reforms since the 1991 Constitution, current revenues rose to 15.3 percent of GDP in 2003, up from 8.8 percent in 1990. The net result has been an increase in the central government's fiscal deficit, especially after 1995 . The adjustment measures adopted since 1999 (when the deficit reached a peak of 6.7 percent of GDP) have stopped -but not reversed- that trend. The growing gap between the overall and the primary deficit reflects the large increase in public debt and interest payments during the second half of the 1990s. ${ }^{60}$

We argue that the capacity to conduct stable and predictable fiscal policies (i.e., avoiding and rapidly correcting deficits) has been severely hindered since the 1991 Constitution. This is not only the result of additional expenditures "imposed" by the Constitution, ${ }^{61}$ but also a consequence of the reduction in the degree of flexibility and adaptability of fiscal policies. In turn, the greater rigidity in fiscal decisions is a natural response to the difficulty in reaching cooperative solutions in the environment created by the 1991 Constitution, characterized by lesser presidential powers and a larger number of relevant political actors. Along these lines, the report of the Comisión de Racionalización del Gasto y de las Finanzas Públicas ${ }^{62}$ (1997) argued that the "growing demand of government services (education, health, justice, security, etc.) and the absolute lack of consciousness on the part of society in relation to the limited resources available" are some of the principal causes of the "difficult fiscal situation" which is characterized by a "limited room of maneuver of the administration" (p. 62). The commission's analysis, as well as many other papers that have followed, have identified interest payments, pensions, and transfers as the key components of government expenditures that "explain" the large imbalances in the sense that these expenditures have increased faster than revenues (see Figure 11). ${ }^{63}$

\footnotetext{
60 Rincón, Berthel and Gómez (2003) find that the component of the fiscal deficit that results from cyclical factors was relatively small between 1980 and 1994 (fluctuating between -0.2 percent and 0.2 percent of GDP), but that the rapid expansion of the economy between 1995 and 1997 raised revenues over their longrun structural trend, lowering the fiscal deficit in as much as 0.4 percent of GDP. Between 1999 and 2002 revenues fell below their long-run value as a result of the recession, adding between 0.2 percent and 0.4 percentof GDP to the fiscal deficit. These results are similar to those of Salazar and Prada (2003), but some-what different from Caballero and Posada (2003).
}

61 The 1991 Constitution was explicit about the need to increase expenditures, especially in the social sectors, with the idea of improving governance while reducing the intensity of the conflict. Ocampo (2004) argues that the decision to raise expenditures was not only deliberate but also had ample support, based on the need to accelerate social progress while strengthening democracy. Among the various possible ways to achieve these goals, the constitution reinforced the model of fiscal and political decentralization, which had gained momentum during the 1980s. The Constitution also reformed the judiciary and imposed the obligation of subsidizing public utilities for a large share of the population.

62 This bipartisan and technical commission was established by the government in 1995 . The purpose was to obtain a set of recommendations for the rationalization of government expenditures. The initiative came from several legislators during the discussion of the 1995 tax reform. 
Figure 11. CENTRAL ADMINISTRATION'S EXPENDITURE EVOLUTION $(1990=\mathbf{1 0 0})$

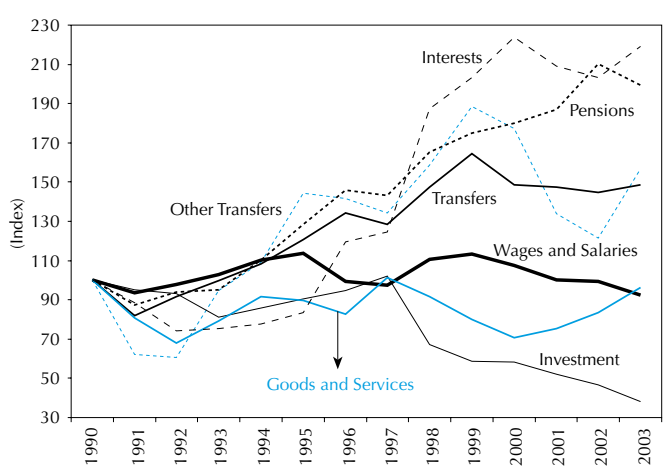

Source: DNP.

On the revenue side, it is important to understand which underlying political and institutional factors explain why tax reforms have been so frequent (on average, every 20 months since 1990), distortionary (introducing anachronistic taxes as well as tax expenditures), and incomplete (never closing the gap with expenditures). The "outer features" in this case suggest high volatility (there have been some policy reversals in relation to tax rates and exemptions), low coherence of tax policies (in the sense that there is very little consistency between reforms), and low capacity to adopt structural reforms that solve longterm problems with measures that have short-term upfront political costs but high long-term payoffs.

\section{Fiscal Transfers to Local Governments}

The process of decentralization has evolved rapidly since 1980. In Colombia, over 40 percent of total government spending is allocated by subnational governments, compared to an average of 15 percent in Latin America. ${ }^{64}$ Subnational governments are larger

\footnotetext{
63 Payroll expenditures and general administrative expenses have remained relatively constant (in proportion to total revenues), while investment is the only item that has fallen (again relative to total revenues).
}

only Argentina and Brazil, the two federal countries in the region. Fiscal decentralization was pushed forward by the 1991 Constitution, which mandated a significant increase in fiscal transfers to the regions (mainly for education and health) to levels that are comparable to those of federal countries. Articles 356 and 357 of the 1991 Constitution ordered a gradual increase in territorial transfers, which were 29 percent of the central government's current revenues in 1990 and were expected to rise to 46.5 percent by the end of that decade. ${ }^{65}$ In practice, fiscal transfers rose faster, to nearly 60 percent of current revenues, suggesting the presence of other factors beyond the constitutional mandate. ${ }^{66}$

In July 1999, worsening economic conditions at home and abroad, led the Pastrana Administration to initiate a formal agreement with the IMF. The core of the program agreed upon was to lower the consolidated public sector (CPS) deficit to 3.5 percent of GDP in 2000, 2.5 percent in 2001, and 1.5 percent in 2002. ${ }^{67}$ The IMF program emphasized the need for a

\footnotetext{
64 In contrast, local taxes account for about 19 percent of total taxes in the country.
}

65 According to Wiesner (1995), decentralization was conceived not only as a policy to induce efficiency from an economic point of view, but as a political instrument to allow greater participation or, more explicitly, as an escape-valve to release some of the pressures that had been built during the years of centralism. The process redistributed power from the national government to the municipalities and, to a lesser extent, to departments (Acosta and Bird, 2003). Critics emphasize low accountability and waste of resources (e.g., Echavarría, Rentería y Steiner, 2003) and the excessive imbalance of social spending on health and education, which has interfered with an efficient use of resources to reduce poverty (Perotti, 2005).

66 One of those factors is Law 188, enacted in 1995, which incorporated new teachers into the system and reclassified them into higher salary categories (effectively increasing salaries by 26 percent in real terms). The national government paid the bill through the Fondo de Compensación Educativa.

67 At the end of 2002, the program was extended for another three-year term. 
constitutional amendment to modify fiscal transfers. Since the 1991 Constitution, these transfers were determined as a fixed share of total current revenues of the national government (which made tax reforms partly ineffective).

The amendment was finally approved by Congress in July 2001. The workings of that policy change illustrate well the incentives and constraints of the political actors. The initial proposal of the government was to replace the system with a guaranteed 1.5 percent real annual increase in fiscal transfers (equivalent to population growth) regardless of economic conditions. In an effort to gather the sympathy of the political class, the government modified the initial proposal and introduced another article, extending the term in office of elected majors and governors from three to four years. Negotiations in Congress raised real growth increase in fiscal transfers to 2 percent per year between 2002 and 2005, and 2.5 percent between 2006 and 2008. ${ }^{68}$ The end result is that the executive had to pay a high price (securing regions with a high growth rate in fiscal transfers) in order to gain a few years of independence between revenues and transfers. ${ }^{69}$ This shows that changing the rigid clauses of the constitution regarding fiscal transfers is politically costly. This, of course, limits the room of maneuver of the executive in economic matters, which cannot adjust expenditures at the local level to overall economic conditions.

However, other reforms introduced in the past few years, as reviewed by Zapata, Acosta and González (2001), have improved matters by redirecting the

68 After 2009, transfers will grow at a rate equal to the average of real growth in current revenues of the central government during the previous four years.

69 In addition, the amendment incorporated the Fondo de Compensación Educativa into the constitutionally mandated level of transfers. use of the fiscal transfers. Law 549 of 1999, created FONPET (a national fund to cover the pension liabilities of the regions). Most of the increase in fiscal transfers to the regions between 2000 and 2002 was channeled through this fund, along with 20 percent of the revenues of the national royalties fund, and the resources from potential future privatizations. Law 617 of 2000 set limits on current expenditures by local governments and has effectively reduced the fiscal deficit at the municipal and department level. Complementing the constitutional amendment, Law 715 of 2001 improved the criteria used for the allocation of fiscal transfers across local governments, using efficiency indicators (such as the enrollment rates or the actual population receiving health subsidies). To end on an optimistic note, this shows that reform has been possible on the margin. Reforms have improved the use and allocation of fiscal transfers, rather than providing some adaptability or flexibility to their overall level.

\section{Other Examples of Embedded Rigidity}

Echeverry, Fergusson and Querubín (2004) discuss other sources of inflexibility in the central government's budget. They distinguish between mandatory expenditures and earmarked revenues. According to the 1991 Constitution, some of these revenues are considered parafiscales in the sense that they are spent by institutions not included in the budget approved by Congress. As they rightly point out, these rigidities have a long tradition in Colombian economic history. Almost every Minister of Finance in the twentieth century complained about the fiscal problems caused by congressional initiatives in relation to expenditures and earmarked taxation. ${ }^{70}$

\footnotetext{
70 See the survey of Memorias de Hacienda, collected in Serna (1988).
} 
For the purpose of this paper it is worth noting that, apart from pensions and transfers to local governments, earmarked expenditures currently represent nearly 1.7 percent of GDP. These expenditures cover almost every single sector (from sports to security), and are rigid in the sense that the budget law cannot change them. In relation to earmarked taxation the estimated figure for 2003 is 3.7 percent of GDP, suggesting that it is a larger problem. It is interesting to note that 79 percent of the existent earmarked rents were created after 1991, indicating that the rules of the political game favor this type of rigidity given the high political transactions costs. The recipients of these taxes are a myriad of funds, created for the development of specific regions and sectors. Recently, earmarked taxation has been used as a way of funding additional military expenditures.

High transaction costs also result in the constitutionalization of fiscal policies. A good example is wage policy in the public sector. Based on its interpretation of Article 53 of the constitution (which says that minimum vital remuneration is a right), the cc has overruled the budget and has mandated minimum public sector salary increases. ${ }^{71}$ Rigidities are so pervasive that the executive had to call a referendum in 2003 in order to freeze government expenditures for two years. The referendum failed.

\section{Taxation}

As discussed above, there has been a deliberate, although insufficient, effort to raise revenues in order to finance larger expenditures. The analysis of the

71 A ruling in 2000 established the previous year's inflation as the minimum increase. In 2001 a new ruling stated that, for public employees with above-average salaries, the wage increase could be less than inflation (but positive in any case). In 2003, the Court determined that the minimum increase could not be less than 50 percent of inflation. contents of recent tax reforms, as well as the formal objectives established in the draft projects, confirm that the major objective of the executive in the tax reform process has been an increase in tax revenues as a means of reestablishing fiscal balances. Even though the priority has been the increase in fiscal revenues, the draft tax reform projects submitted to Congress have given importance to the structure of the tax system, an area in which governments have been only partially successful. There has been an increasing reliance on the vAT rate, which has increased from 10 percent to 16 percent through various reforms since 1990. However, the most recent attempts to increase the main VAT have systematically failed. More importantly, most of the draft projects submitted to Congress have sought to widen the VAT base, with limited success.

As a consequence of Congress' reluctance to widen the income and VAT tax base, the executive has introduced new -and highly distortionary- tax sources. In 1998, a temporary 0.2 percent financial transactions tax was adopted through an emergency decree, which was raised to 0.3 percent and made permanent in the 2000 tax reform, and raised again to 0.4 percent in the 2003 reform. In the same vein, the Uribe government adopted a transitory net wealth tax earmarked for the strengthening of democratic security in Colombia through an extraordinary internal commotion decree. This tax was extended for three additional years in 2003. The conclusion is that revenue pressures have led to decisions that disregard the basic principles of an equitable and efficient tax structure.

The role of Congress as a political actor in tax reforms has been significant. While in earlier decades, Congress largely rubber-stamped the tax reforms submitted by the executive, often through emergency legislation, its involvement in the design of tax packages has been 
increasing since the early 1990 s. On the positive side, Congress has been exemplary, to the extent that it has passed eight tax reforms since 1990. Also, Congress has a solid group of distinguished members with knowledge and expertise on fiscal affairs who lead the debate and who are influential in the outcome of the legislation. On the negative side, Congress could be partly blamed for the insufficiency of revenues that come forth from the reforms, for the increase in expenditures and for the deficiencies in the structure of the taxing system. An analysis of tax legislation submitted by the executive reveals that Congress tends to water down proposals during the debates, both in terms of revenues and, more importantly, in terms of the quality of the reforms.

The growing involvement of Congress in fiscal issues is also illustrated in the significant number of sponsors that are assigned to the analysis of the draft proposals from the executive. As discussed above, the interest in becoming sponsor also has to do with the distribution of pork, or with benefits obtained from the private sector as a result of political favors. The cc has also been a significant actor in tax policy outcomes. Tax issues have represented around 10 percent of the total legal claims on economic matters handled by the cc since 1991. Among the 50 most important rulings on economic matters made by the cc since 1992, 19 have dealt with fiscal issues. In 1999, the ruling on the financial transactions tax limited the scope in the use of resources. More recently, the cc denied the approval of the generalization of the vAT and the taxation of specific activities. At the same time, the cc has given its full legal support to important reforms.

\section{Pension Policy}

As mentioned above, pensions have been the fastest growing public expenditure since 1991. The policymaking process provides another example of an entrenched status quo -unsustainable and unequal- yet extremely hard to reform. Law 100 of 1993, a major reform that had as its main goal the replacement of the pay-as-you-go defined benefit (DB) system for a defined contribution (DC) and individual capitalization scheme, illustrates well the workings of the political process. What came out of the legislative discussion is quite different from the initial government proposal. In particular, the DC regime is not mandatory for new entrants and was offered only as an alternative to the DB system. The reform scaled down some of the benefits of the DB system, especially by raising the retirement age, but the system is structurally unbalanced. In addition, the political compromise was to phase in very slowly the new conditions, which will be fully effective only in 2014. Such a long transitional period has implied growing fiscal deficits. In addition, legislators, workers of the oil sector, teachers, and members of the armed forces, among others, kept their privileged pension regimes, something that has been impossible to change until today. The initial proposal eliminated the DB system, leveled the benefits of all systems in 2004 and only excluded the military from the standard regime.

Even though the reform lowered the implicit pension debt by 38 percent of GDP, mainly as a result of the increase in contribution rates from 6.6 percent to 13.5 percent of wages, the fiscal costs of the new pension system are still unsustainable. As early as 1997, the report of the Comisión para la Racionalización del Gasto Público (1997), Ayala (1998) and Clavijo (1998), among others, proposed shortening the transitional period, raising the retirement age, increasing contributions, reducing the replacement rate, and adopting stricter eligibility criteria. Although under the 1999 IMF program the Colombian authorities had made strict commitments to submit to Congress a second generation pension reform, it was not until December 2002, under the Uribe Administration, that the pension reform was finally approved in Congress. Notwithstanding the high political capital of the new 
administration, the proposed increase in retirement ages starting on 2009 was rejected in Congress. Contributions went from 13.5 percent of wages to 15.5 percent by 2006, while the minimum required number of weeks of contribution was increased. The replacement ratio was also reduced gradually from levels in the range of 65-85 percent to the range of 50-70 percent, and new public workers were obliged to remain in the public pension system for at least the three initial years. Here also, the cc rejected some of the changes. ${ }^{72}$

Many aspects of the pension regime have been set by rulings of the cc. In order to deal with some of these features, the 2003 referendum included a specific question, which was not approved, proposing the elimination of all exempt and special public sector pension regimes and the enrollment of all new entrants in the general pension regime as of 2008. When this paper was being written in 2005, the government was promoting a constitutional amendment in Congress. A balance of results in pension reform indicates this is a politically delicate and costly issue. As in the case of tax reform, draft proposals submitted by the administration are watered down in the congressional debate, especially in relation to changes in benefits. The conclusion is that the executive has initiative but not necessarily control over the final output.

\section{MONETARY AND EXCHANGE RATE POLICIES}

\section{A. Players}

Prior to 1963, decisions on monetary and exchangerate policies were made by a board chaired by the Minister of Finance and composed mostly of

\footnotetext{
72 The increase in the minimum number of weeks of contribution was declared unconstitutional, but it was approved again in the following legislature (Law 860/2003), which again was declared unconstitutional in 2004.
}

prominent private sector bankers. In 1963, these policies were transferred to the government-controlled Monetary board, presided by the Minister of Finance and with the presence of other economic cabinet members, the central bank governor, and support from two technical advisors. ${ }^{73}$ In practice, from 1963 to 1991 , monetary and exchange rate policy decisions were in the hands of the executive. Exchange rate policy from 1967-1991 was based on a crawling peg regime, supported with a strict exchange control. The key policy decision, the rate of crawl, was made by the Minister of Finance in consultation with the President and transmitted to the governor of the central bank for implementation.

The 1991 Constitution (Article 372) established the seven-member central bank board as the monetary and exchange rate authority. The members include the Minister of Finance, who serves as chair, the governor of the central bank, who is elected by the board, and five independent members named by the President for a period of four years. ${ }^{74}$ Only two of the independent members can be changed every four years. The board members, according to the constitutional mandate, must represent only the interest of the nation. The major objectives of the central bank are maintaining the purchasing power of the currency and controlling inflation. Furthermore, the constitution established that lending to the government required the unanimous support of board members.

Even though the central bank board takes its decisions by a majority rule, where each member has one vote, the two most prominent actors within the

\footnotetext{
73 The board of the central bank was kept in charge of the administration of the bank, with the continued presence of private sector bankers.

74 It has been argued that the presence of the Minister of Finance reduces independence but enhances coordination. See Alesina (2004) for a critical analysis.
} 
board are the governor of the central bank and the Minister of Finance, both of whom act as de facto agenda-setters. The governor instructs the bank's staff on the preparation and submission to the board of the technical papers, which gives him great influence. Even though the Minister has only one vote in the board decision process, in practice the board has almost always acted with the support of the Minister in regard to exchange rate issues, and very often at his request. Monetary policy decisions are made on the basis of majority rule, but on most occasions the decision taken has had the acquiescence of the Minister of Finance. Although the Minister of Finance is formally the person in charge of conveying the government's view on exchange policy and interest rate matters, it has not been uncommon, and in fact the rule, for the President himself to provide his own views on these issues.

In relative terms, and compared to other Latin American countries, Colombia's Banco de la República (central bank) has been relatively independent of other branches of government. Nevertheless, such independence was far from complete. In fact, monetary and exchange rate policies undertook a significant turnaround as a result of formal independence, established in 1991. Congress has fared well with the independence of the central bank to the extent that, in terms of executive-legislative relations, it gained relative power since the executive is no longer able to recur to monetary financing from the central bank and is forced to confer with the legislative branch, both in the case of taxes and in authorizations to undertake public lending.

Congress also has an important role in the institutional organization but not in monetary and exchange rate policy formulation. In the first place, the Colombian constitution (Article 371) explicitly establishes that the central bank should present reports to Con- gress on matters for which the bank is responsible, including exchange rate issues and the management of international reserves, and "on other issues that may be required". The constitution also establishes that one of the roles of Congress, besides enacting the central bank law that regulates the constitutional mandate to the board, is its responsibility for determining the exchange rate regime. In 1991, Congress approved two important pieces of legislation regarding central bank board functions (Ley 31 de 1991) and the exchange rate regime (Ley 9 de 1991). In every legislative period, Congress discusses the Banco de República Reports and summons the Minister of Finance, the Governor and the board members for difficult and strict questionings regarding central bank policies.

Initiatives to modify the central bank's mandate have not been uncommon (see Table 12). However, only one initiative out of 70 was approved by Congress, and it was later rejected by the cc. Two of these were debated in Senate committees, and 14 did not have any course through Congress. The one approved was presented by president's Samper Administration in 1996 and was clearly directed to modify the role of the board of Banco de la República as the exchange rate authority of the country. Other initiatives have been geared towards the explicit acceptance of the "employment" objective as one of the main goals of the actions of the board and to subject its members to a censure vote, a political action that Congress can apply to cabinet ministers. While it is true that the number of initiatives to change the exchange rate authority of the central bank board has increased in recent years, it is also a fact that the number of legislators that try to push these initiatives through Congress is quite small. Ultimately, however, Congress has not been successful in reforming the framework established by the constitution in 1991 and by the central bank law of 1991 (Ley 31 of 1991). 


\begin{tabular}{|c|c|c|c|c|}
\hline Type of Proposal & Year & Iniciative & Contents of Proposal & Result \\
\hline Constitutional Reform & 1996 & $\begin{array}{l}\text { Government } \\
\text { (Samper) }\end{array}$ & Exchange regime as Presidential function & Not approved \\
\hline Constitutional Reform & 1996 & $\begin{array}{l}\text { Government } \\
\text { (Samper) }\end{array}$ & Modify central bank objectives & $\begin{array}{l}\text { Approved but rejected by Constitutional } \\
\text { Court on procedural matters }\end{array}$ \\
\hline Constitutional Reform & 1999 & $\begin{array}{l}\text { Government } \\
\text { (Pastrana) }\end{array}$ & Employment as a central bank objective & Without procedural course in Congress \\
\hline $\begin{array}{l}\text { Constitutional Reform } \\
\text { (Acto Legislativo 08) }\end{array}$ & 1998 & $\begin{array}{l}\text { Congress } \\
\text { (H.S. Camilo Sánchez) }\end{array}$ & Modify central bank functions (Article 373) & Without procedural course in Congress \\
\hline $\begin{array}{l}\text { Constitutional Reform } \\
\text { (Acto Legislativo } 76 \text { ) }\end{array}$ & 1998 & $\begin{array}{l}\text { Congress } \\
\text { (H.S. Camilo Sánchez) }\end{array}$ & Censure motion to central bank board members & Without procedural course in Congress \\
\hline $\begin{array}{l}\text { Constitutional Reform } \\
\text { (Acto Legislativo 06) }\end{array}$ & 1999 & $\begin{array}{l}\text { Congress } \\
\text { (H.R. Pablo Ardila) }\end{array}$ & Censure motion to central bank board members & Retired \\
\hline $\begin{array}{l}\text { Constitutional Reform } \\
\text { (Acto Legislativo 06) }\end{array}$ & 1999 & $\begin{array}{l}\text { Congress } \\
\text { (H.S. Camilo Sánchez) }\end{array}$ & $\begin{array}{l}\text { Growth and employment as central bank } \\
\text { objectives }\end{array}$ & Without procedural course in Congress \\
\hline $\begin{array}{l}\text { Constitutional Reform } \\
\text { (Acto Legislativo 10) }\end{array}$ & 2000 & $\begin{array}{l}\text { Congress } \\
\text { (H.S. Flora Sierra) }\end{array}$ & Censure motion to central bank board members & Without procedural course in Congress \\
\hline $\begin{array}{l}\text { Constitutional Reform } \\
\text { (Acto Legislativo 203) }\end{array}$ & 2001 & $\begin{array}{l}\text { Congress } \\
\text { (H.R. Rafael Amador) }\end{array}$ & Modify central bank functions & Without procedural course in Congress \\
\hline $\begin{array}{l}\text { Constitutional Reform } \\
\text { (Acto Legislativo 08) }\end{array}$ & 2002 & $\begin{array}{l}\text { Congress } \\
\text { (H.S. Camilo Sánchez) }\end{array}$ & Censure motion and central bank functions & $\begin{array}{l}\text { Passed first debate in Senate, without } \\
\text { additional procedural course }\end{array}$ \\
\hline Legal (Proyecto 76) & 1998 & Congress & Central bank board menbers barred from office & Without procedural course in Congress \\
\hline Legal (Proyecto 83) & 1999-2000-2002 & $\begin{array}{l}\text { Congress } \\
\text { (H.S. Camilo Sánchez) }\end{array}$ & $\begin{array}{l}\text { Central bank board members barred } \\
\text { from office }\end{array}$ & Without procedural course in Congress \\
\hline Legal (Proyecto 178) & 2001 & $\begin{array}{l}\text { Congress } \\
\text { (H.S. Humberto Gómez) }\end{array}$ & Faculty to establish interest rate margin ceilings & Without procedural course in Congress \\
\hline $\begin{array}{l}\text { Constitutional Reform } \\
\text { (Acto Legislativo 12) }\end{array}$ & 2003 & $\begin{array}{l}\text { Congress } \\
\text { (H.S. Juan Fernando Cristo) }\end{array}$ & $\begin{array}{l}\text { Central bank functions, board } \\
\text { accountability, bank board structure. }\end{array}$ & $\begin{array}{l}\text { Approved by Senate Commission, } \\
\text { without additional procedural Course }\end{array}$ \\
\hline $\begin{array}{l}\text { Constitutional Reform } \\
\text { (Acto Legislativo 03) }\end{array}$ & 2001 & $\begin{array}{l}\text { Government } \\
\text { (Uribe-Political Reform) }\end{array}$ & $\begin{array}{l}\text { Congress - Amendment to include censure motion } \\
\text { to board members }\end{array}$ & Amendment was retired from project \\
\hline $\begin{array}{l}\text { Constitutional Reform } \\
\text { (Acto Legislativo 168) }\end{array}$ & 2003 & $\begin{array}{l}\text { Congress } \\
\text { (H.R. Francisco Pareja) }\end{array}$ & Employment as a central bank objective & Retired \\
\hline Legal (Proyecto 235) & 2003 & $\begin{array}{l}\text { Congress } \\
\text { (H.R. Francisco Pareja) }\end{array}$ & Censure motion and central bank functions & Retired \\
\hline
\end{tabular}

Reference should be made as well to the role of the judiciary branch of government. Table 13 refers to CC rulings that are thought to have had major implications for economic policymaking in Colombia. It can be seen that out of 50 major rulings by the cc between 1992 and 2003, covering a wide range of areas related to the economy, only six had to do with the workings of the central bank and only one ( $N^{\circ} 481$ of 1999) had substantial implications for the board, since the cc ruled that the objectives of the bank include both inflation control and economic growth. Normally, the cc has ruled in favor of the central bank's independence by limiting the role of the government in exchange rate and monetary ma- 
Table 13. CONSTITUTIONAL COURT RULINGS WITH MAJOR EXCHANGE POLICY IMPLICATIONS

\begin{tabular}{lccll}
\hline Type of Sentences & Year & Number & \multicolumn{1}{c}{ Topic } & Decision \\
\hline Constitutional & 1993 & 408 & CONPES functions on exchange rates issues & Unanimous \\
Constitutional & 1999 & 481 & Central bank objectives (Growth) & One side vote \\
Constitutional & 1999 & 383 & Interest rate indexing - DTF & Two side votes \\
Constitutional & 1999 & 702 & Interest rate capitalization & One side vote \\
Constitutional & 2000 & 208 & Central bank powers to control interest rates (Inexequible) & Three side votes \\
Constitutional & 2000 & 955 & Indexing with uvR - ceilings & Four side votes \\
Constitutional & $1992-2003$ & Total mayor & All economic areas & \\
& & &
\end{tabular}

Source: Constitutional Court.

tters. While defending that, the cc has also become more active in issues that were previously reserved to economic authorities, such as caps on mortgage interest rates. Regarding decisions made by the Consejo de Estado, in general they have confirmed and reiterated the role of the bank's board as the foreign exchange and exchange rate authority in the country. The major conclusion found in the case of the Consejo de Estado is that it has acted as an enforcer of intertemporal agreements.

The role of multilateral organizations, particularly the IMF, as well as the us Treasury has also been important. In 1999, during the final stages of negotiation of the IMF program, both the IMF and the Treasury held that Colombia should switch from the exchange rate band system to a flexible regime, and this view ultimately prevailed. Colombian private sector interest groups, the academic community, the press and public opinion in general have limited influence on the formulation of exchange rate policy.

\section{B. Framework}

Before 1991, access to central bank liquidity facilities benefited greatly the government through monetary deficit financing. The system gave preferential credit access to particular activities, according to sector problems and pressures. Since 1991, the central bank has been prohibited from extending direct loans to the private sector, except in the case of liquidity facilities to the financial sector. Although lending to the government is theoretically possible, it requires a unanimous vote by the board.

In regard to exchange rate issues, discontent with the old regime became evident around 1987. Urrutia (1994) notes that by the end of the 1980s the strongest argument for maintaining the controls was the fact that Colombia had only had one exceptional balance of payments crisis since the controls were adopted in 1967; moreover, no distinguishable interest group was being favored by the control scheme. Despite this, President Gaviria's reform proposal found support in Congress and among public opinion because the effectiveness of the foreign exchange control system had decreased. Even though the crawling peg regime coped with periods of booms and busts, it was unable to prevent prolonged periods of over and undervaluation of the currency. Besides, exchange controls provoked misallocation of resources.

Although it is tempting to suggest that monetary independence was a strategic decision by the Constitutional Assembly in order to curb the fiscal deficit (especially after a constitution so rich in additional 
mandatory expenditures), the reality is that monetary reform was pushed directly by the central bank, inspired by changing international attitudes towards monetary and exchange-rate regimes. According to the Washington Consensus, central bank independence gave priority to the control of inflation and prevented monetary financing of government fiscal deficit. The change in the central bank regime in Colombia was just one of a significant set of structural reforms covering taxes, labor, trade liberalization, decentralization, social security, and the financial sector adopted at the beginning of the 1990s under the Gaviria Administration (see Edwards and Steiner, 2000).

Consequently, since 1991 the Banco de la República has managed exchange rate policy with considerable independence and flexibility. From 1994 to 1999 the board established an explicit exchange rate band, and during that period, the Colombian authorities established controls on short-term capital inflows, similar to those employed in Chile. ${ }^{75}$ It should be noted that since 1999 the determination of the nominal exchange rate has been more flexible, with some intervention by the bank. On the monetary front, the central bank staff presents to the board a monthly Inflation Report and recommendations on the policy stance. Decisions to adjust interest rates (i.e., lombard and intervention rates) are made by a majority vote of the board of directors.

\section{Features and Outcomes}

Monetary and exchange rate policies have tended to be stable in Colombia. In the pre-1991 years, political interference was limited to the President (and ministers in charge of agriculture and industry), while Congress was excluded from this policy area.

75 Cárdenas and Barrera (1997) and Ocampo and Tovar (1999) discuss their effects.
Post-1991, policies have been formally delegated and have thus become more independent. Volatility or policy reversals associated with changes in the political landscape have been prevented by an institutional design that stresses substantial coordination between the executive and the monetary authority, which has always been high.

The possibility of accelerating the rate of the exchange rate crawl made the crawling peg regime, in principle, a very flexible system. Political constraints, however oftentimes did not allow the implementation of required adjustments in the nominal rate. This explains the failures to adjust and the prolonged periods of over and undervaluation observed. Post1991, the exchange rate band system has been managed in a more flexible way: both the width of the band and its central parity were changed when fundamentals required it. Nonetheless, the system was still too rigid, and a run on the currency occurred in 1999. Authorities subsequently moved to a flexible regime with explicit intervention rules, and the current system undoubtedly experiences much less political interference.

Overall, the inflation-targeting framework adopted in 1999 allows for more flexibility when compared to the rigid rules that guided the increase in monetary aggregates, which prevailed since the 1960s. Inflation targeting allows the monetary aggregates to fluctuate according to the changes observed in money demand. It can be shown that the pre-1991 monetary framework presented smaller interest rate fluctuations, at the cost of inflation rates in the range of 20 to 30 percent from the 1960s to the mid-1990. With the adoption of the inflation-targeting framework, deliberate interest rate adjustments adopted by the central bank board have been more frequent, with resulting gains in terms of reducing inflationary expectations and achieving one-digit inflation. 
A final distinguishing aspect between the pre and post1991 regimes relates to differences in the policies' public or private regardedness. The crawling peg system was often accompanied by multiple rates favoring specific groups. While a tax was generally imposed on coffee exports (and also on oil proceeds), importers of certain types of goods (i.e., capital imports) obtained foreign exchange at relatively more favorable terms. In contrast, the current flexible regime leads to a single market-determined rate for most goods and services. Also, subsidized credit was previously directed toward certain sectors of the economy that not always chosen on technical grounds.

Finally, it does not appear that changes in the government in Colombia, or in political ideology, have made a substantial difference in the way exchange rate policy has been conducted and implemented. Under the crawling peg regime the variation of the nominal exchange rate responded to discretionary management, but the real rate followed economic fundamentals. The behavior of the exchange rate between 1991 and 1999 and afterwards, when the exchange rate band was eliminated, was more strongly determined by fundamentals and market perceptions. There is no evidence that political pressures or party orientation have influenced the evolution of the exchange rate.

\section{A General Characterization of Policies' Outer Features}

Sections 7 and 8 of this paper have provided a detailed account of the outer features of fiscal, monetary, and exchange rate policies in Colombia before and after 1991. Table 14 summarizes the main findings. In the case of fiscal policies, the main changes are related to the adaptability of policies. In most areas, fiscal policies became more rigid after the 1991 Constitution (except in the case of pensions, where policies have been always rigid). There has been a slight deterioration regarding stability vis-à-vis political shocks, but also a marginal improvement in terms of public regardedness.

Table 14. CHARACTERIZATION OF POLICIES BEFORE AND AFTER THE 1991 CONSTITUTION: OUTER FEATURES

\begin{tabular}{|c|c|c|c|c|c|c|c|c|}
\hline & \multicolumn{2}{|c|}{ Stability* } & \multicolumn{2}{|c|}{ Adaptability** } & \multicolumn{2}{|c|}{ Coherence } & \multicolumn{2}{|c|}{ Public regardedness } \\
\hline & Before & After & Before & After & Before & After & Before & After \\
\hline \multicolumn{9}{|l|}{ Fiscal Policy } \\
\hline Fiscal Transfers & Medium & Medium & Medium & Low & Medium & Medium & Medium & High \\
\hline Pensions & Medium & Medium & Low & Low & Medium & Medium & Low & Medium \\
\hline Other expenditures & Medium & Low & Medium & Low & Medium & Medium & Medium & Medium \\
\hline Taxes & Medium & Medium & Medium & Low & Medium & Low & Medium & Medium \\
\hline Coffee & High & - & High & - & High & - & High & - \\
\hline Oil & - & High & - & Medium & - & High & - & High \\
\hline Monetary policy & Medium & High & High & Medium & Medium & High & Low & High \\
\hline Exchange rate policy & Medium & High & Medium & High & Medium & High & Medium & High \\
\hline \multicolumn{9}{|l|}{ Other areas not covered in the paper } \\
\hline Trade policy & Low & Low & High & Medium & Low & Medium & Low & Low \\
\hline Regulation of public utilities & Low & Medium & Low & Medium & Low & Medium & Low & High \\
\hline Financial policies & Medium & Medium & Medium & Medium & Medium & Medium & Low & High \\
\hline Labor policies & High & High & Low & Low & Medium & Medium & High & High \\
\hline Social policies (health and education) & Medium & Medium & Medium & Low & Medium & Medium & Medium & Medium \\
\hline
\end{tabular}


In regards to monetary and exchange rate management, policies since 1991 have been more isolated from political shocks. Compared to the period pre1991, monetary policy has been (at least until 1999) less adaptable to external shocks, while the opposite was true for the exchange rate. There is more coordination/coherence in these two policy areas, and both have clearly gained in terms of public regardedness. An indication of this last point is the fact that special privileges such as differentiated exchange rates and subsidized credit facilities were eliminated after 1991.

It is important to explore, in a cursory manner, other policy areas to provide a more general outlook of the effects of the 1991 Constitution. Trade policy is an area that has remained relatively isolated from political changes, although it is less used now than in the past to deal with economic shocks, for reasons that have to do with the trade agreements signed since 1991. Trade policies still display private regardededness in the sense of including some forms of protection that are not openly discussed outside the executive.

Regulation of public utilities is an area where much progress has been achieved since the 1991 Constitution. The regulatory commissions operate with relative autonomy from the executive, although not to the point observed in monetary policies. With the important exception of the water commission, these commissions have largely been able to produce regulation that is stable and adaptable. However, the most important advancement in these areas is related to the public regardedness of the decisions made.

Finally, in the case of financial policies, the main feature is related to the lower degree of stability, adaptability, and coherence since 1991. In some areas, such as mortgage finance, certain decisions are in the hands of the $\mathrm{Cc}$, which by definition limits the response to economic shocks. Labor policies are still very rigid, although isolated from political shocks. Social policies have lost adaptability, as in the case of fiscal policies in general. In short, the evidence is mixed. Some areas of policies show an improvement while in others there is deterioration. Clearly, in many policy areas the 1991 Constitution brought positive changes. The main problems are associated with fiscal policies.

\section{CONCLUSIONS}

At the end of the 1980s Colombian political institutions were under severe strain. Large segments of the population demanded more political participation and inclusion after decades of bipartisan control. Regional political leaders, with the support of the electorate, advocated fiscal and political decentralization. The call for increased security and political stability was particularly loud after a decade of growing unrest and conflict that ended with the assassination of three presidential candidates in 1989. Moreover, the expectation of greater resources available from oil discoveries, as well as the exacerbation of social tensions, created momentum for the long-debated need of a new constitution. The sentiment surrounding this issue found expression in the elections of 1990, which included an unofficial vote in favor of rewriting the constitution, and the 1991 Constitution became an escape valve that released some of the pressures that had been built in the previous decades. More sectors were brought into democratic life, barriers to political participation were lowered, and regions gained autonomy and greater administrative independence. In sum, after several failed attempts, the reform came from within the system.

The new political institutions have had a significant effect on the policymaking process and policy outcomes in a variety of areas. The constitution reduced presidential powers, enhanced the role of Con- 
gress, lowered the costs of political participation and brought into the policymaking processes two new key players: the Constitutional Court and the board of the central bank. In addition, some policy areas, such as fiscal transfers, social expenditures, wages, and pensions, were embedded in the constitution, thus restricting the executive's room for maneuver. Moreover, in those cases in which there is some constitutional flexibility, the executive has faced a more divided and fragmented Congress, which has increased political transaction costs and has lowered the probability of approval of bills. Apart from the quantitative aspect, bills that are approved are typically watered down relative to executive proposals.

In addition, the use of special legislative powers by the executive was severely restricted, while the regular constitutional review of laws is now more active, independent, and detailed. As a result, fiscal policies are less adaptable and flexible, precisely at the time when the economy faces larger external shocks than in the past. We argue that deconstitutionalizing some aspects of fiscal policy could improve policy outcomes in this area.

The reduction in presidential powers has also affected monetary policy. Although the President is still influential, through the presence of the Minister of Finance in the central bank's board, policies often deviate from the preferences of the executive. Although disinflation has been the overriding goal of monetary policy since 1991, the evidence suggests that monetary policy has become more flexible and adaptable since 1999, the year when inflation returned to single-digit figures. In this case we do not propose major reforms of the political institutions that are relevant for monetary policy.

Recently, two constitutional amendments were approved. On the one hand, for the first time in Colombia's modern history, there was a successful attempt at reforming the electoral system for all legislative bodies. On the other, Congress approved a constitutional amendment allowing the President to run for a consecutive second term. Although there were attempts in Congress to extend the possibility of re-election to all executive offices, including mayors and governors, this was finally rejected.

These reforms will change the political institutions in important ways. Instead of choosing across hundreds of lists, voters will choose candidates from single party lists. This will encourage formal pre-electoral coalitions and more policy-based campaigns. ${ }^{76} \mathrm{Al}-$ though post-electoral coalitions will remain a relative salient feature of the system, due to the existence of the preferential vote, changes across party lines will imply more costs to members who decide to move from their pre-electoral coalition. Thus, as in Shugart, Moreno and Fajardo (2005), we anticipate a reduction in the number of lists and the consolidation of a multiparty system.

In addition, as a result of reelection we expect an increased role of the President in congressional elections. Depending on the president's level of popularity, elections will allow voters to punish or reward the government as well as legislators aligned with the executive. It will also enlarge the probability of what we have called here "the intertemporal agreement," due to longer time horizons for both members of Congress and the executive. The existence of a second term will reinforce the party organizations at the national level. However, the fact that reelection for other offices are not allowed might leave the local and regional party apparatus somehow disjointed from this process. In

77 For a description and explanation of the changes and implications of the electoral reform, see Shugart, Moreno and Fajardo (2005). 
addition, the reelection of the President will limit the independence of the central bank.

Reforms have already changed the incentives for political organizations. The "independents," for example, were previously a disorganized group, but they have consolidated their forces into a very heterogeneous coalition, Polo Democrático, with electoral success. The traditional parties are trying to adapt to the new electoral system, but it remains to be seen whether their effort at reinforcing discipline succeeds. In addition, legislative initiatives have begun to insist on defining the status and powers of opposition parties in Congress.
The constitutional reform of 1991 was an important attempt to restore representation and legitimacy to the political regime. However, as shown in our paper, the existence of excessive fragmentation and short-term horizons has had a negative impact on a variety of policies. Transactions cost have been high due to personalistic incentives and lack of organization. Most likely, the electoral reform will remedy in part the dysfunctionality of the party system. Hopefully, this will translate into more programmatic policy that reinforces political party labels instead of personalistic agendas. Finally, reelection will consolidate the power of the President as the main agenda-setter in the policymaking processes. 


\section{REFERENCES}

Acosta, O.L., and R. Bird (2003), "Evaluación de las recomendaciones sobre impuestos locales en la reforma estructural del sistema tributario colombiano y estudio y recomendaciones sobre la situación de los ingresos tributarios de los departamentos". Estudios para la Misión del Ingreso Público. Toronto, Canada: University of Toronto. Mimeographed document.

Aghion, P., A. Alesina and F. Trebbi (2004), "Endogenous Political Institutions". Quarterly Journal of Economics 119(2): 565-612.

Amorim-Neto, O. (1998), "Of Presidents, Parties, and Ministers: Cabinet Formation and Legislative Decision-Making Under Separation of Powers". San Diego, United States: University of California, San Diego. Doctoral dissertation.

Amorim-Neto, O. and H. Borsani (2004), "Presidents and Cabinets: The Political Determinants of Fiscal Behavior in Latin America". Studies in Comparative International Development 39(1): 3-27.

Amorim-Neto, O. and F. Santos (2003), "The Inefficient Secret Revisited: The Legislative Input and Output of Brazilian Deputies". Legislative Studies Quarterly 28(3): 449-479.

Archer, R.P. and M.S. Shugart (1997), "The Unrealized Potential of Presidential Dominance in Colombia". In: S. Mainwaring and M.S. Shugart, editors. Presidentialism and Democracy in Latin America. New York, United States: Cambridge University Press.

Arrieta, C.G., and Universidad de los Andes (1991), Narcotráfico en Colombia: Dimensiones políticas, económicas, jurídicas e internacionales. Bogotá, Colombia: Ediciones Uniandes and Tercer Mundo Editores.

Ayala, U. (1998), "La regulación de los fondos de pensiones en América Latina: Reseña y lecciones de la experiencia". Coyuntura Económica 28(4): 189-209.

Bates, R. (1997), "Open-Economy Politics: The Political Economy of the World Coffee Trade". Princeton, United States: Princeton University. Mimeographed document.

Botero, F. (1998), "El Senado que nunca fue: La circunscripción nacional después de tres elecciones". In: A. Dávila Ladrón de Guevara and A.M. Bejarano, editors. Elecciones y Democracia en Colombia: 1997-1998. Bogotá, Colombia: Universidad de los Andes, Departamento de Ciencia Política.

Caballero, C., and C.E. Posada (2003), "Una nota sobre elementos coyunturales y estructurales del déficit fiscal en el caso colombiano reciente". Borradores de Economía No. 235. Bogotá, Colombia: Banco de la República.
Cárdenas, M. (2001), "Economic Growth in Colombia: A Reversal of "Fortune'?" CID Working Paper 83. Cambridge, United States: Harvard University, Center for International Development.

Cárdenas, M., and F. Barrera (1997), "On the Effectiveness of Capital Controls: The Experience of Colombia During the 1990's". Journal of Development Economics 54(1): 27-57.

Cárdenas, M., and Z. Partow (1998), "Oil, Coffee and the Dynamic Commons Problems in Colombia". Research Network Working Paper R-335. Washington, DC, United States: InterAmerican Development Bank, Research Department.

Carroll, R., G.W. Cox and M. Pachón (2004), "How Parties Create Electoral Democracy, Chapter 2". Paper prepared for the Annual Meeting of the American Political Science Association, September 2-5, Chicago, Illinois.

Carrasquilla, A. (2003), "La sostenibilidad de la deuda pública". Bogotá: Ministerio de Hacienda y Crédito Público.

Cepeda, M.J. (2004), "La defensa judicial de la Constitución: Una tradición centenaria e ininterrumpida". In: F. Cepeda, editor. Fortalezas de Colombia. Washington, DC, United Status: Inter-American Development Bank.

(1985), "Estado de Sitio y Emergencia Económica". Bogotá, Colombia: Contraloría General de la República.

Chacón, M. (2004), "Dinámica y determinantes de la violencia durante "La Violencia" en Colombia". Documento CEDE, ISSN 1657-5334. Bogotá, Colombia: Centro de Estudios so-bre Desarrollo Económico (CEDE).

Clavijo, S. (1998), "Pension Reform in Colombia: Macroeconomic and Fiscal Effects". Documento CEDE 98-01. Bogotá, Colombia: Centro de Estudios sobre Desarrollo Económico (CEDE).

Comisión de Racionalización del Gasto y de las Finanzas Públicas (1997), El saneamiento fiscal, un compromiso de la sociedad. Final Report (six volumes). Bogotá, Colombia: Ministerio de Hacienda y Crédito Público.

Cox, G. and M.D. McCubbins (2001), "The Institutional Determinants of Economic Policy". In: S. Haggard and M.D. McCubbins, editors. Presidents, Parliaments, and Policy: Political Economy of Institutions and Decisions. Cambridge, United Kingdom: Cambridge University Press.

Dornbusch, R. and S. Edwards, editors (1991), The Macroeconomics of Populism in Latin America. Chicago, United States: University of Chicago Press.

Dugas, J. (2001), "The Origin, Impact and Demise of the 19891990 Colombian Student Movement: Insights from Social 
Movement Theory". Journal of Latin American Studies 33(4): 807-37.

Echavarría, J.J., C. Rentería and R. Steiner (2003), "Descentralización y salvamentos (bailouts) en Colombia". Coyuntura Social 28.

Echeverry, J.C., L. Fergusson and P. Querubín (2004), "La batalla política por el presupuesto de la Nación: Inflexibilidades o supervivencia fiscal". Document CEDE, ISSN 1657-5334, Bogotá, Colombia: Centro de Estudios sobre el Desarrollo Económico.

Edwards, S., and R. Steiner (2000), "On the Crisis Hypothesis of Economic Reform: Colombia 1989-91". Cuadernos de Economía 112: 445-493.

Escobar, A. (1996), "Ciclos políticos y ciclos económicos en Colombia: 1935-1994." Coyuntura Económica (junio).

Fajardo, L.E., E. Moreno and M. Shugart (2003), "Deepening Democracy by Renovating Political Practices: The Struggle for Electoral Reform in Colombia". Revision of a paper originally prepared for the conference, "Democracy, Human Rights, and Peace in Colombia", Kellogg Institute, Notre Dame University, Notre Dame, Indiana, March 26-27, 2001.

Gallón, G. (1978), Quince años de estado de sitio en Colombia: 1958-1978. Bogotá, Colombia: Editorial América Latina.

Gutiérrez, F. (2003), "Fragmentación electoral y política tradicional en Colombia: Piezas para un rompecabezas en muchas dimensiones." Working Paper 24. London, United Kingdom: London School of Economics, Development Research Centre.

(2001), "¿Se ha abierto el sistema político colombiano? Una evaluación de los procesos de cambio (1970-1998)". América Latina Hoy 27: 189-215

(1999), "La reforma política: Una evaluación crítica". Pensamiento Jurídico. Revista de Teoría del Derecho y Análisis Jurídico 11. Bogotá, Colombia: Universidad Nacional de Colombia, Facultad de Derecho, Ciencias Políticas y Sociales.

Haggard, S. and M.D. McCubbins, editors (2001), Presidents, Parliaments, and Policy: Political Economy of Institutions and Decisions. Cambridge, United Kingdom: Cambridge University Press.

Hartlyn, J. (1981), "Consociational Politics in Colombia: Confrontation and Accommodation in Comparative Perspective". New Haven, United States: Yale University. Doctoral dissertation.

Hartlyn, J. (1993), La Política del Régimen de Coalición. Bogotá, Colombia: Tercer Mundo Editores, UniAndes-CEI.
Hoskin, G., F. Leal and H. Kline (1976), Legislative Behavior in Colombia. Buffalo, United States: Council on International Studies.

International Monetary Fund -IMF- (2004a), "Stabilization and Reforms in Latin America: A Macroeconomic Perspective of the Experience Since the 1990s". Washington, DC, United States: IMF, Western Hemisphere Department.

(2004b), "Descentralización fiscal en Colombia." Washington, DC, United States: IMF, Public Finance Department. Mimeographed document.

Laakso, M. and R. Taagepera (1979), "The Effective Number of Parties: A Measure with Application to Western Europe". Comparative Political Studies 12(1): 3-27.

Levitt, S. and M. Rubio (2005), "Understanding Crime in Colombia and What Can be Done About It". In: A. Alesina, editor. Institutional Reforms: The Case of Colombia. Cambridge, United States: MIT Press.

Lleras, C. and M. Tangarife (1996), Constitución Política de Colombia Origen: Evolución y Vigencia. Bogotá, Colombia: Biblioteca Jurídica Diké.

Mainwaring, S. and T. Scully (1995), "Introduction: Party Systems in Latin America" in S. Mainwaring and T. Scully, editors. Building Democratic Institutions: Party Systems in Latin America. Stanford, United States: Stanford University Press.

Mejía-Acosta, A. (1998), "Partidos políticos: El eslabón perdido de la representación". In: F. Pachano, editor. La ruta de la gobernabilidad. Quito, Ecuador: Corporación de Estudios para el Desarrollo.

Misión del Ingreso Público (2003), Cuadernos de Fedesarrollo 10. Bogotá, Colombia: Fedesarrollo.

Morgenstern, S., and B. Nacif (2002), Legislative Politics in Latin America. Cambridge, United Kingdom: Cambridge University Press.

Nielson, D.L., and M.S. Shugart (1999), "Constitutional Change In Colombia: Policy Adjustment Through Institutional Reform". Comparative Political Studies 33(3): 313-341.

Ocampo, J.A. (2004), "Entre las reformas y el conflicto: economía y política en Colombia". New York, United States: United Nations. Mimeographed document.

Ocampo, J.A., and C. Tovar (1999), "Flujos de capital, ahorro e inversión en Colombia 1990-1996". In: R. Ffrench-Davis and $\mathrm{H}$. Reisen, editors. Flujos de capital e inversión productiva: Lecciones para América Latina. Santiago, Chile: CEPAL, OECD and McGraw Hill.

Pachón Buitrago, M. (2002), "El Partido Conservador y sus dinámicas políticas". In: F. Gutiérrez, editor. Degradación 
o Cambio: Evolución del Sistema Político Colombiano. Bogota, Colombia: IEPRI-Norma.

(2003), "Explaining the Performance of the Colombian Congress: Electoral and Legislature Rules, and Interactions with the executive". Paper prepared for the 2003 Meeting of the Latin American Studies Association, Dallas, United States, March 27-29.

2004. "Congreso y partidos políticos en Colombia: Una mirada a las instituciones." In: F. Cepeda, editor. Fortalezas de Colombia. Bogota, Colombia: Ulloa Editorial.

Payne, J.L. (1968), Patterns of Conflict in Colombia. New Haven, Colombia: Yale University Press.

Payne, M., A. Adsera and C. Boix (2003), "Are You Being Served? Political Accountability and Quality of Government". Journal of Law, Economics and Organization 19(2): 445-490.

Perotti, R. (2005), "Public Spending on Social Protection in Colombia: Analysis and Proposals". In: A. Alesina, editor. Institutional Reforms: The Case of Colombia. Cambridge, United States: MIT Press.

Pizarro, E. (1995), "La Comisión para la Reforma de los Partidos". Análisis Político 26: 72-87.

Posada-Carbó, E. (2001), "La reformulación de la Paz". Bogota, Colombia. Mimeographed document. http://www. ideaspaz.org/articulos/download/31 lareformulacion-delapaz. pdf

Rincón, H., J. Berthel and M. Gómez (2003), "Balance fiscal estructura y cíclico del Gobierno Nacional Central de Colombia, 1980-2002". Borradores de Economía No. 246. Bogota, Colombia: Banco de la República.

Rocha, R. (1999), La economía colombiana tras 25 años de narcotráfico. Bogota, Colombia: United Nations Drug Control Programme.

Rodriguez-Raga, J.C. (2001), "¿Cambiar todo para que nada cambie? Representación, sistema electoral y sistema de partidos en Colombia: capacidad de adaptación de las élites políticas a cambios en el entorno institucional". In: F. Gutiérrez, editor. Degradación o cambio: Evolución del sistema político colombiano. Bogotá, Colombia: IEPRI-Norma.

(1999), "Posibilidades y riesgos de la actual reforma electoral en Colombia: un análisis del sistema electoral colombiano". Pensamiento Jurídico 11: 203 - 214.

Roland, G., and J.G. Zapata (2005), "Colombia's Electoral and Party System: Possible Paths for Reform". In: A. Alesina, editor. Institutional Reforms: The Case of Colombia. Cambridge, United States: мIT Press.

Rosenthal, H. and M. Kugler (2005), "Checks and Balances: an Assessment of the Institutional Separation of Political Powers in
Colombia". In: A. Alesina, editor. Institutional Reforms: The Case of Colombia. Cambridge, United States: MIT Press.

Salazar, N. and D. Prada (2003), "Hay que recuperar la política fiscal". Carta Financiera No. 124. Bogotá, Colombia: Asociación Nacional de Instituciones Financieras.

Samuels, D. (2003), Ambition, Federalism, and Legislative Politics in Brazil. Cambridge, United Kingdom: Cambridge University Press.

Sarmiento Buitrago, L. (1985), "El estatuto jurídico de la emergencia". In: M.J. Cepeda, editor. Estado de sitio y emergencia económica. Bogotá, Colombia: Contraloría General de la República.

Scartascini, C., and M. Olivera (2003), "Political Institutions, Policymaking Processes and Policy Outcomes: A Guide to Theoretical Modules and Possible Empirics". Design Paper \#2 for the Red de Centros Project "Political Institutions, Policymaking Processes and Policy Outcomes". Washington, DC, United States: Inter-American Development Bank.

Serna, J.G. (1988), Aspectos de la política presupuestal en Colombia 1886-1987. Bogotá, Colombia: Ministerio de Hacienda y Crédito Público.

Shugart, M.S., E. Moreno and L. Fajardo (2005), "Deepening Democracy by Renovating Political Practices: The Struggle for Electoral Reform in Colombia". In: A. Alesina, editor. Institutional Reforms: The Case of Colombia. Cambridge, United States: MIT Press.

Spiller, P., E. Stein, and M. Tommasi (2003), "Political Institutions, Policymaking Processes and Policy Outcomes: An Intertemporal Transactions Framework". Design Paper \#1 for the Red de Centros Project "Political Institutions, Policymaking Processes and Policy Outcomes". Washington, D.C., United States: Inter-American Development Bank.

Spiller, P. and M. Tommasi (2003), "The Institutional Foundations of Public Policy: A Transactions Approach with Application to Argentina". Journal of Law, Economics and Organization 19(2): 281-306.

Taylor-Robinson, M., and C. Díaz (1999). "Who Gets Legislation Passed in a Marginal Legislature and is the Label Marginal Legislature Still Appropriate?". Comparative Political Studies 32: 590-626.

Tsebelis, G. (2002), Veto Players: How Political Institutions Work. Princeton, United States: Princeton University Press.

United Nations Office on Drugs and Crime (2004), World Drug Report 2004. New York, United States: United Nations.

Urrutia, M. (1996), "Política económica e instituciones". Borradores de Economía 52. Bogotá, Colombia: Banco de la República. 
(1994), "Colombia". In: J. Williams, editor. The Political Economy of Policy Reform. Washington, DC, United States: Institute of International Economics.

(1991), "On the Absence of Economic Populism in Colombia". In: R. Dornbusch and S. Edwards, editors. The Macroeconomics of Populism in Latin America. Chicago, United States: University of Chicago Press/National Bureau of Economic Research.

Villar, L. (2004), "Inflación y Finanzas Públicas". Borradores de Economía No. 297. Bogotá, Colombia: Banco de la República.

Weaver, R.K., B.A. Rockman (1993), "Assessing the Effects of Institutions". In: R.K. Weaver and B.A. Rockman, editors. Do Institutions Matter? Government Capabilities in the United States and Abroad. Washington, DC, United States: Brookings Institution.
Wiesner, E. (1995), La descentralización, el gasto social y la gobernabilidad en Colombia. Bogotá, Colombia: Departamento Nacional de Plantación, Asociación Nacional de Institutciones Financieras and Financiera de Desarrollo Territorial.

(2004), "El origen político del déficit fiscal en Colombia: El contexto institucional 20 años después". Documento CEDE No. 20-2004. Universidad de los Andes.

Zapata, J.G., O.L. Acosta and A. González (2001), "Evaluación de la descentralización municipal en Colombia. ¿Se consolidó la sostenibilidad fiscal de los municipios colombianos durante los años noventa?". Archivos de Economía No. 165. Bogotá, Colombia: Departamento Nacional de Planeación. 